Maurer School of Law: Indiana University

Digital Repository@ Maurer Law

Indiana Law Journal

Volume 95 | Issue 2

Article 3

$4-15-2020$

\title{
The Replicability Crisis in Patent Law
}

Janet Freilich

Fordham Law School, jfreilich1@fordham.edu

Follow this and additional works at: https://www.repository.law.indiana.edu/ilj

Part of the Law and Economics Commons, Law and Society Commons, Property Law and Real Estate Commons, and the Science and Technology Law Commons

\section{Recommended Citation}

Freilich, Janet (2020) "The Replicability Crisis in Patent Law," Indiana Law Journal: Vol. 95 : Iss. 2 , Article 3.

Available at: https://www.repository.law.indiana.edu/ilj/vol95/iss2/3

This Article is brought to you for free and open access by the Law School Journals at Digital Repository @ Maurer Law. It has been accepted for inclusion in Indiana Law Journal by an authorized editor of Digital Repository @ Maurer Law. For more information, please contact rvaughan@indiana.edu.

\section{$\Psi$}

JEROME HALL LAW LIBRARY

INDIANA UNIVERSITY

Maurer School of Law
Bloomington 


\title{
The Replicability Crisis in Patent Law
}

\author{
JANET FREILICH ${ }^{*}$
}

There is a "replicability crisis" in the scientific literature. Scientists attempting to redo experiments in reputable, peer-reviewed journals have found that staggering numbers of these experiments-up to 90\%-do not work. Patents, like scientific articles, contain experiments. These experiments often form the backbone of the patent and provide crucial support for patentability. Patent examiners use these experiments to evaluate whether the invention works, and thus whether the patent should be granted. The replicability crisis in the scientific literature is therefore of utmost importance to the patent system. Transferring the insights of the replicability crisis to patents begs the question of whether experiments in patents are similarly irreplicable - a question that has not previously been asked in the literature.

This Article's novel empirical study of 500 patents and applications measures the replicability of experiments in patents. Using methodological quality of the experiment as a proxy for replicability, this study finds that experiments in patents have very poor methodological quality, which means that they are likely irreplicable at rates at least as high as experiments in scientific journals.

Given the centrality of experiments to patents, this Article's empirical finding is a crisis not only of replicability, but also of patent law, and has important implications for patent doctrine, theory, and policy. Patent law relies on the assumption that, when a patent is filed, it has been "reduced to practice"-meaning that the invention works. The reality is that most inventions likely do not work, casting serious doubt on this assumption. Similarly, the underlying justification for patents-incentivizing innovation-requires that they contain enough information to teach others how to make and use the invention. Irreplicable patents may not do this. In short, there is a fundamental mismatch between patent law's theory and doctrine, which treat patents as reflecting fully formulated inventions, and what patents often represent, which is early stage, frequently unproven, results. The replicability literature-and the findings of this Article-teach us that experiments reported in patents are not reliable enough to merit the level of control and influence that they are granted in the patent system.

This Article argues that patent law cannot solve irreplicability; instead, patent theory must better reflect the reality of irreplicability. Several policy proposals flow from this reformulation, including easing the process of invalidating inoperable patents, improving disclosure of ex post data in patents, and clarifying the experimental use exception.

* Associate Professor, Fordham Law School. I thank Yonathan Arbel, Nestor Davidson, Deborah Denno, Rochelle Dreyfuss, Wendy Gordon, Clare Huntington, Yotam Kaplan, Margot Kaminski, Joseph Kupferman, Mark Lemley, Jonathan Masur, Laura PedrazaFariña, Nicholson Price, David Schwartz, Jacob Sherkow, Victoria Stodden, Katherine Strandburg, Harry Surden, Polk Wagner, and participants at the Junior Faculty Forum for Law and STEM, Regulation and Innovation in the Bioscience, Roundtable on Empirical Methods in Intellectual Property, Tri-State IP Conference, and Fordham Faculty Workshop. For excellent research assistance, I thank Jennifer Lei, Adam Mengler, Meredith Miller, and Allison O'Hara. 
CONTENTS

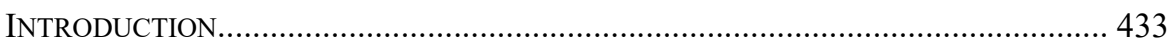

I. UNDERSTANDING IRREPLICABILITY ........................................................ 438

A. The Replicability Crisis in Science ................................................... 439

1. Causes of Irreplicability........................................................ 441

2. Costs of Irreplicability ...................................................... 442

B. Replicability and the Patent System ............................................... 442

1. The Role of Experiments in Patents............................................ 443

a. Why Patentees Use Experiments......................................... 443

2. Incentives and Disincentives for Replicability .......................... 445

a. Patentee Incentives .......................................................... 445

b. Examiner Incentives............................................................ 446

II. MEASURING IRREPLICABILITY IN PATENTS: AN EMPIRICAL STUDY................ 448

A. Methodology ................................................................................ 448

1. Testing Replicability ....................................................... 448

2. Checklist for Replicability .............................................. 451

3. Sample .............................................................................. 453

B. Results .............................................................................. 456

1. Methodological Quality of Experiments in Patents ................... 456

2. Validating the Measure .......................................................... 458

a. Association with Lawyers and Clients ................................ 459

b. Patent-Product Link ............................................................ 460

c. Patent-Paper Pairs ................................................................ 461

3. PTO Rejections and Patent Grant ............................................. 462

4. Change Over Time..................................................................... 464

5. Industry and Academia ............................................................ 464

C. Mechanism ...................................................................................... 465

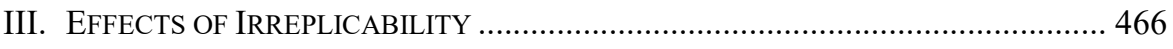

A. Implications for Patent Law................................................... 467

1. Waste and Inefficiency .......................................................... 467

2. Inoperable Patents............................................................... 467

a. Inoperable Patents Can Cover Operable Technology........... 468

b. Inoperable Patents Can Still Be Valid................................ 469

c. Harm from Inoperable Patents .......................................... 470

3. Impeding the Goals of the Patent System ............................... 471

4. Experimentation Stops.............................................................. 471

B. Implications for Patent Theory and Scholarship .............................. 473

1. Probabilistic Functionality ....................................................... 474

2. Functionality as a Spectrum................................................... 475

3. Patent Law Cannot Solve Irreplicability................................... 477

C. Adapting Patent Law to an Irreplicable World................................... 479

1. Clarify the Experimental Use Exception .................................... 479

2. Ease Process of Invalidating Irreplicable Patents ....................... 480

3. Disclose Ex Post Data......................................................... 481

4. Strategic Ex Ante Improvements .......................................... 481

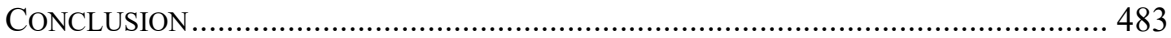




\section{INTRODUCTION}

For the past decade, scientists have grappled with a "replicability crisis"- the widespread finding that many, if not most, results published in scientific journals cannot be replicated. Studies attempting to replicate preclinical experiments have found that almost $90 \%$ of experiments from well-respected, peer-reviewed journals are not replicable. ${ }^{1}$ The cost of irreplicability is enormous - economists estimate that a conservative $50 \%$ irreplicability rate in preclinical research in the United States alone would cost $\$ 28$ billion per year. ${ }^{2}$ Irreplicability is also blamed for our inability to translate promising preclinical research into effective human treatments, which delays bringing lifesaving drugs to market. ${ }^{3}$ The replicability crisis is a high priority for institutions such as the National Institute for Health $(\mathrm{NIH})^{4}$ and the National Science Foundation (NSF), ${ }^{5}$ and hundreds of prominent scientific journals have devised formal policies to combat irreplicability. ${ }^{6}$ Though these policies have not been effective, ${ }^{7}$ their prevalence underscores the gravity of the problem.

The replicability crisis has critical implications for patent law. ${ }^{8}$ Patents, like scientific articles, often contain experimental data. ${ }^{9}$ These experiments are linked to the underlying justification for the patent grant: experimental data are used to prove that the invention actually works, that the inventor in fact invented the technology, and to teach others how to make and use the invention. ${ }^{10}$ While experimental data are common in the patent system, the replicability crisis in the scientific literature teaches us that most experiments do not work. The obvious question is whether experiments in patents are replicable.

This Article is the first empirical study to assess whether experiments in patents are replicable. I demonstrate empirically that, like scientific articles, replicability is

1. E.g., C. Glenn Begley \& Lee M. Ellis, Raise Standards for Preclinical Cancer Research, 483 NATURE 531, 532 (2012).

2. Leonard P. Freedman, Iain M. Cockburn \& Timothy S. Simcoe, The Economics of Reproducibility in Preclinical Research, PLoS Biology, June 2015, at 1.

3. Jack W. Scannell \& Jim Bosley, When Quality Beats Quantity: Decision Theory, Drug Discovery, and the Reproducibility Crisis, PLOS ONE, Feb. 2016, at 2.

4. Francis S. Collins \& Lawrence A. Tabak, NIH Plans to Enhance Reproducibility, 505 NATURE 612, 612 (2014).

5. Subcomm. on Replicability in Sci., Advisory Comm. to the Nat'l Sci. Found. Directorate for Soc., Behavioral, and Econ. Scis., Soc., Behavioral \& Econ. Scis. Perspectives on Robust AND Reliable Science 2 (2015), https://www.nsf.gov/sbe/AC _Materials/SBE_Robust_and_Reliable_Research_Report.pdf [https://perma.cc/W9YUC4SX].

6. See, e.g., Victoria Stodden, Jennifer Seiler \& Zhaokun Ma, An Empirical Analysis of Journal Policy Effectiveness for Computational Reproducibility, 115 PROC. NAT'L ACAD. SCI. 2584, 2584 (2018).

7. See infra Section I.A.4.

8. Jacob S. Sherkow, Patent Law's Reproducibility Paradox, 66 Duke L.J. 845, 845 (2017).

9. Janet Freilich, Prophetic Patents, 52 U.C. DAVIS L. REV. (forthcoming 2019) (manuscript at 8) (on file with the Indiana Law Journal).

10. See infra Part I. 
also at crisis levels for experiments in patents - that perhaps up to $90 \%$ of such experiments do not work.

I assess the replicability of experiments in patents by measuring their methodological quality, scoring methodological quality using a checklist developed by the journal Nature. ${ }^{11}$ Methodological quality has been validated as a proxy for replicability in the scientific literature. ${ }^{12}$ The rationale behind the proxy is that experiments that omit basic techniques to ensure reliability such as randomization or statistical analysis are less likely to be replicable. I compare the methodological quality scores of experiments in patents and experiments reported in the scientific literature. Because experiments from the scientific literature are known to be frequently irreplicable, if experiments in patents have comparably low methodology quality scores, then experiments in patents are likely also frequently irreplicable.

I hand-coded a random sample of 500 preclinical experiments from patents and applications and scored their methodological quality. I found that these experiments have very poor methodological quality. Only $62 \%$ of experiments in patents in my sample disclosed sample size, $12 \%$ were randomized, $4 \%$ were blinded, $2 \%$ conducted replicate studies, and $63 \%$ had statistical analysis of any kind. ${ }^{13}$ This is worse than the methodological quality in scientific papers, where more than $70 \%$ of experiments disclosed their sample size, approximately $15 \%$ were randomized, approximately $20 \%$ were blinded, and over $90 \%$ included statistical analysis. ${ }^{14}$ These methodological quality numbers in scientific papers are often used to support the existence of a replicability crisis, ${ }^{15}$ so the lower numbers in patents suggest that a crisis exists there too.

I additionally validate my methodology for use in patents. Poor methodological quality may reflect poor experimental design, or it may reflect poor experimental reporting. For instance, an experiment may be well designed, but the drafting patent attorney may omit methodological detail from the patent. Though the connection between quality of experimental design and quality of experimental reporting has been confirmed in scientific articles, patents are written using different conventions and for different purposes, so the link may not be present in patents. ${ }^{16}$

I use several approaches to connect quality of methodological reporting with quality of methodological design. First, I show that patents covering FDA-approved drugs have better methodological quality than their non-commercialized counterparts. ${ }^{17}$ These patents are commercialized and are—hopefully—replicable ${ }^{18}$,

11. Nature Publ'g Grp., Reporting Life Sciences Research (2015), https://www.nature.com/authors/policies/reporting.pdf [https://perma.cc/5ETD-YLSX].

12. See infra Section II.A.1.

13. See infra Table 3.

14. These numbers are approximate because many studies have used this method to assess methodological quality in scientific papers, and results differ somewhat between the studies. None of the studies assessed whether replicates were disclosed. See infra Table 3 and accompanying footnotes.

15. See infra Section II.A.

16. See Lisa Larrimore Ouellette, Do Patents Disclose Useful Information, 25 HARV. J.L. \& TECH. 531, 561 (2012).

17. See infra Section II.B.2.b.

18. See Sherkow, supra note 8 , at 845 (arguing that, to the detriment of human health, 
suggesting that better reported methodology correlates with genuine quality of experiment. Second, I show that methodological quality is correlated with the scientific institution filing the patent but is not correlated with the law firm drafting the patent. ${ }^{19}$

I looked specifically at life sciences patents because these patents are the most likely to contain experiments ${ }^{20}$ and because the replicability crisis in the scientific literature is most often discussed in the context of life sciences research. ${ }^{21}$ However, though I focused on the life sciences here, replicability is likely a problem across all industries - although the reasons may be different in different industries. ${ }^{22}$

My findings have consequences for patent law, as a foundational assumption of patent law is that inventions work. ${ }^{23}$ Patents incentivize innovation by granting exclusive rights to inventors who have created something socially useful. ${ }^{24}$ While society pays higher prices for the product during the term of the patent, in exchange, society gets access to a useful invention and the invention is disclosed in sufficient detail that others can learn from and build upon the invention. ${ }^{25}$ If most inventions in patents do not work and are not replicable, neither of those goals is achieved.

This crisis of replicability in patent law occurs because of a structural mismatch between the process of invention and the way that patents function in practice. Patents are filed early in the life cycle of an invention and many of the experiments reported in patents are preliminary investigations into the functionality of the invention. ${ }^{26}$ Preliminary experiments are, by their nature, somewhat speculative and will often be proven wrong by later, more intensive experimentation. ${ }^{27}$ However, while the experiments that provide evidence for patentability are tentative, the rights that attach to the patent are not. On the basis of early-stage experiments that are often incorrect, the patentee gets the powerful legal right to exclude others from making or using the invention. ${ }^{28}$ These rights are practically permanent for the life of the patent - a granted patent is presumed valid and is therefore difficult to challenge in litigation. ${ }^{29}$ The replicability literature - and the findings of this Article - teaches

some Orange Book listed patents are not replicable).

19. See infra Section II.B.2.a.

20. Freilich, supra note 9, at fig. 1.

21. See infra Section I.A.1. However, there are also replicability crises in other disciplines, most notably psychology. E.g., Monya Baker, Over Half of Psychology Studies Fail Reproducibility Test, NATURE NEws (Aug. 27, 2015), https://www.nature.com/news/over -half-of-psychology-studies-fail-reproducibility-test-1.18248 [https://perma.cc/34NX-9KD3].

22. Lisa Larrimore Ouellette, Who Reads Patents?, 35 NATURE Biotech. 421 supp. fig.4 (2017) (explaining that when researchers were asked, "Do you think you could recreate the invention described in the most recent patent you read in your field?" fewer than $45 \%$ of researchers in any field answered affirmatively).

23. See, e.g., Wiesner v. Weigert, 666 F.2d 582, 588 (C.C.P.A. 1981).

24. U.S. Const. art. I, $\S 8$, cl. 8 .

25. J.E.M. AG Supply, Inc. v. Pioneer Hi-Bred Int'l, Inc., 534 U.S. 124, 126 (2001).

26. Ted Sichelman, Commercializing Patents, 62 StAn. L. Rev. 341, 343 (2010).

27. See infra Section III.A.

28. 35 U.S.C. $\S 271$ (2012).

29. Id. § 282(a). 
that experiments of the sort reported in patents are not reliable enough to merit this level of control and influence. ${ }^{30}$

The mismatch between early-stage experiments and long-term patent rights creates several practical problems. First, because a patent's scope is generally broader than the experiments that support the patent, an irreplicable experiment can be used to obtain a patent that covers technology that does work-dampening incentives for downstream innovation. ${ }^{31}$ Thus, if an inventor conducts an experiment that shows that a new drug treats cancer in mice, a patent obtained on the strength of that finding will cover any use of the drug - to treat cancer, to treat any other disease, or even for a non-medical use, such as use as shoe polish. If it is later found that the inventor was entirely wrong (the drug does nothing to treat cancer) another inventor who finds an actual valuable use for the drug (say, to treat HIV) must obtain a license from the patent holder..$^{32}$ Although the first inventor's patent may not be valid, ${ }^{33}$ it is time-consuming and expensive to prove invalidity in court, and so an inoperable patent can still be used to collect rents from innovators developing operable technology. ${ }^{34}$

Irreplicable experiments can cause additional harms. Patents on technologies that do not work overload the patent system, burdening examiners, creating patent thickets, and providing fodder for patent trolls. ${ }^{35}$ Moreover, they create considerable waste, since the labor and materials that went into conducting the experiment are squandered. ${ }^{36}$

In addition, to the extent that the patent literature has considered the issue of inoperable patents, it is to speculate on the consequences of patents on technology that has not been physically created or tested. ${ }^{37}$ That misses a much wider, and more troubling, problem - that even patents that have been tested may not work. Additionally, there is a longstanding recognition that the Patent and Trademark

30. See infra Section III.B.1.

31. See infra Section III.A.1.2.a.

32. This is loosely based on the real story of the development of azidothymidine (AZT). Alice Park, The Story Behind the First AIDS Drug, Time (Mar. 19, 2017), https://time.com/4705809/first-aids-drug-azt/ [https://perma.cc/2ZKN-FWSG].

33. Patents must be operative to be valid. Metropolitan Eng. Co. v. Coe, 78 F.2d 199 (D.C. Cir. 1935). Inoperative patents, or patents supported by many experiments that do not work, may also be invalid for failure to satisfy the enablement requirement. 35 U.S.C. $\S \S 101$, 112 (2012). However, not every patent with an irreplicable experiment will be invalid. See infra Section I.B.1.

34. Leveraging the cost of litigation to extract rents is a common "patent troll" strategy. Doug Lichtman \& Mark A. Lemley, Rethinking Patent Law's Presumption of Validity, 60 STAN. L. REV. 45, 48 (2007).

35. See, e.g., James Bessen \& Michael Meurer, Patent Failure: How Judges, BurEauCrats, AND LAWYERS Put INNOVATORS AT RisK 68 (2008).

36. See infra Section I.A.2.

37. See, e.g., Christopher A. Cotropia, The Folly of Early Filing in Patent Law, 61 Hastings L.J. 65, 72 (2009); Mark A. Lemley, Ready for Patenting, 96 B.U. L. REV. 1171, 1195 (2016); Lisa Larrimore Ouellette, Pierson, Peer Review, and Patent Law, 69 VAND. L. REV. 1825, 1830 (2016); Sean B. Seymore, Heightened Enablement in the Unpredictable Arts, 56 UCLA L. REV. 127, 145 (2008). 
Office (PTO) frequently grants patents in error. ${ }^{38}$ These so-called "bad patents" can be the result of PTO mistakes in any of the numerous requirements of patentability, however, the scholarship - and successful policy reform from Congress-has focused on the PTO's failure to enforce the novelty and nonobviousness requirements. ${ }^{39}$ There has been comparatively little scholarship on the PTO's failure to ensure that patents are useful and teach others how to make and use the invention - both of which are requirements for patentability. ${ }^{40}$ My findings suggest that these failures frequently lead to erroneously granted patents and scholars should therefore devote considerably more attention to the topic.

The replicability crisis in patent law, in short, calls for a fundamentally different relationship between functionality and patenting that better reflects the actuality of how science progresses and how patents are filed. Because it would be prohibitively expensive to delay patenting until all inventions are shown to work ${ }^{41}$ the better solution is to reconceptualize patent law to adapt to the reality that we do not know if patented inventions are functional.

This Article proposes several reforms. First, patent law should make it easier to update experimental disclosure and to identify and invalidate patents based on irreplicable experiments. Currently, if a third-party attempts to replicate an experiment from a patent, she risks infringement. ${ }^{42}$ The experimental use exception should be clarified to eliminate this risk. ${ }^{43}$ Second, I propose a system to collect data obtained after patent filing. ${ }^{44}$ Thus, if a patentee later finds that the experiment is irreplicable, that finding will be attached to the patent. Finally, I suggest reducing the cost and time needed to invalidate irreplicable patents, specifically removing the presumption of operability and considering procedures outside the courtroom to assess questions of enablement and utility. ${ }^{45}$

The Article proceeds as follows: Part I explains the irreplicability crisis in the scientific literature. It then discusses the role of experiments in patents, why such experiments might be irreplicable, and the harm irreplicable experiments in patents could cause. Part II reports on the Article's core empirical study, explaining the study's methodology and, most importantly, laying out the study's results. Part III explores the implications of the empirical findings and suggests policy reform.

38. Mark A. Lemley, Rational Ignorance at the Patent Office, 95 Nw. U. L. REV. 1495, 1496 (2001).

39. See infra Section III.B.1.

40. See infra Section III.B.1.

41. See infra Section III.A.

42. See infra Section III.B.1.

43. See infra Section III.B.1.

44. See infra Section III.B.3.

45. See infra Section III.B.2. 


\section{UNDERSTANDING IRREPLICABILITY}

Before filing a patent, inventors must show that their invention works and can be recreated by others. ${ }^{46}$ To be sure, the inventor need not fully test the invention, ${ }^{47}$ nor create a commercially viable version ${ }^{48}$ - in fact, the inventor need not even create a physical model of the invention ${ }^{49}$ - but the inventor must have some evidence that the invention is functional. A mere hunch is insufficient, as are "[c]rude and imperfect experiments. ${ }^{, 50}$ Further, while the inventor need not provide instructions on every last detail of how the invention could be replicated, patents must contain enough information that others could recreate the invention without "undue experimentation." ${ }^{51}$

During the patent application process, a patent examiner will review the application and determine if the invention fulfills the utility and enablement doctrines. ${ }^{52}$ The former requires that an invention be useful, ${ }^{53}$ and the latter requires that the invention be described in sufficient detail that other scientists can make and use the invention..$^{54}$ Both doctrines require that the invention be functional, since an invention that does not work is not useful, nor can it be made and used by others. ${ }^{55}$ Additionally, the enablement doctrine implicitly requires replicability, because if a patent does not disclose sufficient details for replication, others cannot easily make and use the invention without undue experimentation. ${ }^{56}$ Patent applications that fulfill the utility and enablement requirements, along with the other requirements of

46. E.g., Mycogen Plant Sci., Inc. v. Monsanto Co., 243 F.3d 1316, 1332 (Fed. Cir. 2001) ("To establish an actual reduction to practice, the inventor must show that . . the invention would work for its intended purpose.”); Loral Fairchild Corp. v. Matsushita Elec., 266 F.3d 1358, 1362-63 (Fed. Cir. 2001) ("Once the invention has been shown to work for its intended purpose, reduction to practice is complete.”); DSL Dynamics Scis. Ltd. v. Union Switch \& Signal, Inc., 928 F.2d 1122, 1125 (Fed. Cir. 1991) (requiring patentees to show that "the embodiment relied upon as evidence of priority actually worked for its intended purpose").

47. Taskett v. Dentlinger, 344 F.3d 1337, 1342 (Fed. Cir. 2003) ("That Dentlinger did not test this step of the counter under conditions of actual use does not mean that he did not reduce it to practice. His test was sufficient to determine that the invention would work for its intended purpose.").

48. Id. ("To hold otherwise would be to require an inventor to have created a viable commercial embodiment before the Board or a court could find reduction to practice. This the law does not require.").

49. See, e.g., The Telephone Cases, 126 U.S. 1, 535-36 (1888) (upholding a patent granted to Alexander Graham Bell even though Bell had not created a working version of the telephone before filing the patent application. The Court noted that Bell had written a set of instructions on how to make a telephone - instructions that were accurate - and that this was sufficient to enable his patent). See also Pfaff v. Wells Elecs., Inc., 525 U.S. 55, 56 (1998) (applying the rule from The Telephone Cases).

50. Seymour v. Osborne, 78 U.S. 516, 517 (1870).

51. In re Wands, 858 F.2d 731, 737 (Fed. Cir. 1988).

52. 35 U.S.C. $\S \S 101,112$ (2012).

53. Brenner v. Manson, 383 U.S. 519, 528-29 (1966).

54. Alcon Research Ltd. v. Barr Labs., Inc., 745 F.3d 1180, 1188 (Fed. Cir. 2014).

55. U.S. Patent and Trademark Office, Manual of Patent Examining Procedure $\S 2164.07$ (9th ed. 2018) [hereinafter MPEP].

56. 35 U.S.C. $\S 112$. 
patentability, will be granted by the patent examiner. ${ }^{57}$ After grant, the patent is presumptively valid, meaning that the patent system assumes the utility and enablement requirements are met and, consequently, that the patent works and can be replicated. ${ }^{58}$ While this presumption can be challenged in litigation, the challenger bears the burden of proving lack of utility and enablement. ${ }^{59}$

The assumption that inventions described in patents work and are replicable not only underlies the validity analysis, but also is a foundational part of how the patent system determines patent scope and inventorship. The scope of the patent should correspond to the scope of the invention; so, we limit the scope of a patent to the aspects of the invention that the patentee could make work. ${ }^{60}$ In addition, patents should be granted to the inventor of the claimed invention, and the inventor is generally thought of as the person who makes the invention work. ${ }^{61}$ Further, patents are supposed to disclose useful information about how to make and use new technologies ${ }^{62}$ and instructions on how to make and use a product that does not work or instructions that cannot be replicated are not helpful. In short, if an invention does not work, the patent system as applied to that invention does not work. The functionality and replicability of inventions are foundational assumptions upon which the patent system stands. ${ }^{63}$

The problem is that a lot of inventions probably don't work.

\section{A. The Replicability Crisis in Science}

The replicability crisis in science is fundamentally about the discovery that many inventions that we thought worked actually do not work-even when the inventors are reputable scientists, even when the invention has been thoroughly peer reviewed, and even when the invention is published in a prominent, respected journal. ${ }^{64}$

Replicability is the ability of scientists to redo an experiment. ${ }^{65}$ For example, a study might find that a drug shrinks tumors in mice. Scientists attempting to replicate the experiment will test the drug in a new set of mice, following the protocol of the

57. Id.

58. Impax Labs. Inc. v. Aventis Pharm. Inc., 468 F.3d 1366, 1383 (Fed. Cir. 2006).

59. Id. at 1378 .

60. E.g., Plant Genetic Sys. v. DeKalb Genetics Corp., 315 F.3d 1335, 1339-40 (Fed. Cir. 2003); In re Vaeck, 947 F.2d 488, 495 (Fed. Cir. 1991) (“[T]he first paragraph of $\S 112$ requires that the scope of the claims must bear a reasonable correlation to the scope of enablement provided by the specification." (citing In re Fisher, 427 F.2d 833, 839 (C.C.P.A. 1970))).

61. E.g., Newkirk v. Lulejian, 825 F.2d 1581, 1582 (Fed. Cir. 1987) (“[P]roof of actual reduction to practice requires demonstration that the embodiment relied upon as evidence of priority actually worked for its intended purpose.") (citing Wiesner v. Weigert, 666 F.2d 582, 588 (C.C.P.A. 1981) (" $[\mathrm{I}]$ nvention is not reduced to practice until its practicability or utility is demonstrated pursuant to its intended purpose ....")).

62. 35 U.S.C. $\S 112(a)(2012)$.

63. Infra Section III.A.3.

64. See Scannell \& Bosley, supra note 3, at 2 .

65. This is distinct from reproducibility, which is the ability to rerun an analysis from the same set of data. Steven N. Goodman, Daniele Fanelli \& John P.A. Ioannidis, What Does Research Reproducibility Mean?, 8 Sci. Translational Med. 341, 341 (2016). 
original experiment as closely as possible. Irreplicability occurs when an experiment is redone and the original results cannot be repeated. ${ }^{66}$ In the example above, the replicators might find that when done again, the drug does not affect the size of tumors in mice. Irreplicability means that the experiment does not work. Irreplicable experiments tell us something about the world that is not true.

One well-known attempt at experimentally replicating previous work found that an astonishing $89 \%$ of preclinical experiments in the fields of hematology and oncology were irreplicable ${ }^{67}$ The replicability team specifically chose "landmark" studies, so the irreplicable papers were not obscure, poorly regarded works, but were instead quite the opposite.$^{68}$ Another attempt at experimentally replicating preclinical studies in oncology, women's health, and cardiovascular disease found that only 20 $25 \%$ of the studies were replicable. ${ }^{69}$ An attempt at replicating mouse trials of drugs to treat amyotrophic lateral sclerosis (ALS) found that a striking $0 \%$ of the drugs showed any beneficial effect when the experiments were replicated. ${ }^{70}$ Venture capital firms, which often assess the viability of early-stage data, have an "unspoken rule" that "at least $50 \%$ of published studies, even those in the top-tier academic journals, 'can't be repeated with the same conclusions by an industrial lab." ${ }^{.71}$ A survey of researchers by the journal Nature found that over $70 \%$ of researchers failed to replicate a reported experiment, and over $50 \%$ failed to replicate their own experiments. $^{72}$

Irreplicability is not just about failure to replicate precise results; rather, the irreplicability crisis has garnered so much attention because the big ideas from studies could not be repeated. ${ }^{73}$ Even well-regarded studies that were cited hundreds of times could not be replicated. ${ }^{74}$ Human trials - carefully reviewed by the FDAwere based on preclinical studies that were later found to be irreplicable. ${ }^{75}$ Irreplicability is therefore about more than just failure of a study to work when tried again; it is about a multitude of spectacular, impactful failures that have thrown the scientific world into crisis. Irreplicability impedes our ability to make scientific progress, to innovate, and ultimately to produce lifesaving technologies.

66. There are many different measures of replicability and no clear agreement on how close one must be to the original to be considered replicable. Stefan Schmidt, Shall We Really Do It Again? The Powerful Concept of Replication is Neglected in the Social Sciences, 13 ReV. Gen. Psychol. 90, 91 (2009).

67. Begley \& Ellis, supra note 1, at 532. This study is called "best-known" by editors of the journal Nature. Monya Baker, Is There a Reproducibility Crisis? 533 NATURE 452, 452 (2016).

68. Begley \& Ellis, supra note 1, at 532 .

69. Florian Prinz, Thomas Schlange \& Khusru Asadullah, Believe It Or Not: How Much Can We Rely on Published Data on Potential Drug Targets?, 10 Nature Revs. Drug DisCOVERY 712, 712-13 (2011).

70. Steve Perrin, Make Mouse Studies Work, 507 NAture 423, 424 (2014).

71. Lev Osherovich, Hedging Against Academic Risk, 4 SCI.-Bus. ExCHANGE 1, 1 (2011).

72. Baker, supra note 67 , at 452 .

73. C. Glenn Begley \& John P.A. Ioannidis, Reproducibility in Science: Improving the Standard for Basic and Preclinical Research, 2015 CiRCULATION RES., 116, 117.

74. Id.

75. Id. 


\section{Causes of Irreplicability}

The causes of irreplicability are varied. Some lack of replicability is caused by improper statistical analysis, including low statistical power and $p$-hacking. ${ }^{76}$ Incentives are also a problem. ${ }^{77}$ Scientists are rewarded (through grant money, promotion, and otherwise) for publishing frequently and in well-regarded journals. ${ }^{78}$ This is more likely to occur if the scientist publishes a result that is positive, novel, and exciting. Researchers studying irreplicability believe that these incentives push scientists to use methodology that increases the likelihood of positive, novel, and exciting results, but decreases the likelihood of replicability. ${ }^{79}$ For instance, there is no incentive to conduct studies on large numbers of samples, or to repeat one's study to ensure that it is correct before publishing. ${ }^{80}$ Further, there is no incentive to publish negative results. ${ }^{81}$

Yet another cause of irreplicability is poor reliability of materials; scientists may be inadvertently working with impure samples or using the wrong cell line..$^{82} \mathrm{~A}$ final cause is poor methodological reporting. ${ }^{83}$ Many studies are reported with insufficient

76. Megan L. Head, Luke Holman, Rob Lanfear, Andrew T. Kahn \& Michael D. Jennions, The Extent and Consequences of P-Hacking in Science, 13 PLoS Biology, Mar. 2015, at 1 (explaining that p-hacking "occurs when researchers try out several statistical analyses and/or data eligibility specifications and then selectively report those that produce significant results").

77. Marcus R. Munafò, Brian A. Nosek, Dorothy V.M. Bishop, Katherine S. Button, Christopher D. Chambers, Nathalie Percie du Sert, Uri Simohnson, Eric-Jan Wagenmaker, Jennifer P. Ware \& John P.A. Ioannidis, A Manifesto for Reproducible Science, 1 NATURE Hum. BeHAV. 21, 22 (2017).

78. E.g., C. Glenn Begley, Alistair M. Buchan \& Ulrich Dirnagl, Institutions Must Do Their Part for Reproducibility, 525 NATURe 25, 25-26 (2015); Francis S. Collins \& Lawrence A. Tabak, NIH Plans to Enhance Reproducibility, 505 NATURE 612, 613 (2014); ("Perhaps the most vexed issue is the academic incentive system."); Elie Dolgin, Drug Discoverers Chart Path to Tackling Data Irreproducibility, 13 NATURE Revs. Drug DisCovery 875, 875 (2014).

79. Andrew D, Higginson \& Marcus R. Munafò, Current Incentives for Scientists Lead to Underpowered Studies with Erroneous Conclusions, 14 PLoS Biology, Nov. 2016, at 1.

80. Id.

81. Brian Nosek, Jeffrey R. Spies \& Matt Motyl, Scientific Utopia: Restructuring Incentives and Practices to Promote Truth Over Publishability, 7 PERSPS. PSYCHOL. SCI. 615, 616 (2012). Failure to publish negative results can lead to the appearance of a positive result that is really due to chance. For instance, let us say that twenty scientists set out to do an experiment. One, by random luck, gets a positive result, while the other nineteen get negative results. The one successful researcher will publish the result, while the other studies are relegated to file drawers; the technique will appear successful, even though it is clearly not (using a p-value of 0.05 , one in twenty positive results will be due to chance).

82. HeLa cells, derived from a cervical cancer sample taken unknowingly from Henrietta Lacks, are one of the most common contaminants in other cell lines. Jill Neimark, The Dirty Little Secret of Cancer Research, Discover MAG. (Oct. 2, 2014), http://discovermagazine.com/2014/nov/20-trial-and-error [https://perma.cc/5Z35-9FSP]. See generally RebeCCA SKLOOt, The IMMORTAL LifE OF HeNRIETTA LACKS 76 (2010) (explaining the history of Henrietta Lacks and HeLa cells).

83. Story C. Landis et al., A Call for Transparent Reporting to Optimize the Predictive Value of Preclinical Research, 490 NATURE 187, 187 (2012). 
details for another team to replicate their procedure ${ }^{84}$ If the replicating team must guess at details, it is not surprising that replication attempt will often fail.

\section{Costs of Irreplicability}

The costs of irreplicability are enormous. Economists estimate that a $50 \%$ irreplicability rate in preclinical research in the life sciences alone would cost $\$ 28$ billion. ${ }^{85}$ One major cost comes from waste-materials, time, and effort spent conducting an experiment that produces misleading results. ${ }^{86}$ The need to check whether experiments are replicable is also costly. Venture capital companies may attempt to replicate experiments before fully investing in a company. Atlas Venture reports that it invests between $\$ 50,000$ to $\$ 500,000$ to validate the data of an earlystage company before making more substantial investments. ${ }^{87}$

There are also non-monetary costs to irreplicability. The first is lack of trust. Irreplicable studies are demoralizing to scientists themselves and also affects the public, as the public's trust in scientific research diminishes. ${ }^{88}$ There are additionally ethical and human costs. To illustrate, in the 1980s, scientists studying the use of high-dose chemotherapy with autologous bone marrow transplant (HDC-ABMT) to treat breast cancer produced promising preliminary results. ${ }^{89}$ These results were so encouraging that patients pushed their doctors to provide the treatment, patient groups lobbied the FDA to allow access, and one woman won $\$ 89$ million in punitive damages against her insurance company for their failure to cover the treatment. ${ }^{90}$ Over the next decade, more than 41,000 patients underwent the treatment. ${ }^{91}$ In the late 1990 s, further studies cast serious doubt on the efficacy of the treatment. ${ }^{92}$ Thousands of women were given false hope and subjected to unnecessary treatment because of irreplicable results.

\section{B. Replicability and the Patent System}

As mentioned above, the patent system is predicated on an assumption that the inventions described in patents actually work. However, many patents are based on scientific experiments, and the dominant conversation for the past decade about scientific experiments has centered around the frequency with which they do not work. The natural question, then, is 'do experiments in patents work'?

In Section I.B.1, below, I provide background on the role of experiments in patents. I discuss when and why patentees include experiments and how experiments

84. Id.

85. Freedman et al., supra note 2, at 1.

86. $I d$.

87. Osherovich, supra note 71 , at 1.

88. Editorial Board, Journals Unite for Reproducibility, 515 NATURE 7, 7 (2014).

89. Michelle M. Mello \& Troyen A. Brennan, The Controversy Over High-Dose Chemotherapy with Autologous Bone Marrow Transplant for Breast Cancer, 20 HEALTH AfF. 101, 103 (2001).

90. Id. at 106-07.

91. Id. at 101.

92. Id. at 105 . 
are used to satisfy various doctrines of patentability. In Section I.B.2, I ask whether we might expect experiments in patents to be replicable. I explore patentee incentives to avoid irreplicability and whether the PTO assesses replicability. I conclude that it is as least plausible that irreplicable experiments are common in patents.

\section{The Role of Experiments in Patents}

The inability of researchers to replicate experiments in the peer-reviewed scientific literature is relevant to patents because experiments are a central component of the patent document. The Constitution empowers Congress to grant patents to "promote the Progress of Science." 93 Patents do this in two ways. First, patents give inventors the exclusive right to make and use their invention, which allows inventors to profit from their inventions and thereby incentivizes the creation of those inventions. ${ }^{94}$ In addition, patents disclose information about new technologies to the public so that the public can then build on and further develop those technologies. ${ }^{95}$ These are part of the basic bargain of the patent system: the patentee gets an exclusive right and, in return, the public gets the creation and disclosure of new technology.

Experiments have two roles in this basic bargain. First, they help prove that patent applicants have in fact invented something that will benefit the public, and second, they facilitate disclosure of information about the technology. Experiments are, therefore, tightly linked to the goals of the patent system.

\section{a. Why Patentees Use Experiments}

Patents do not need to contain experiments. There is no legal requirement that the patented invention be described or supported using experimental evidence. ${ }^{96}$ However, patents, particularly in chemistry and the life sciences, commonly do contain experiments. ${ }^{97}$ The purpose of describing experiments in the patent document is to satisfy the disclosure doctrines: utility, enablement, and written description. ${ }^{98}$ To satisfy those doctrines, the patent document must contain (1) evidence that the invention is useful, ${ }^{99}$ (2) sufficient explanation of the invention that another scientist

93. U.S. CONST. art. I, $\S 8$, cl. 8 .

94. E.g., Dan L. Burk \& Mark A. Lemley, Policy Levers in Patent Law, 89 VA. L. Rev. 1575, 1597 (2003); Matthew B. Hershkowitz, Patently Insane for Patents: A Judge-By-Judge Analysis of the Federal Circuit's Post-Alice Patentable Subject Matter Eligibility of Abstract Ideas Jurisprudence, 28 Fordham InTELl. Prop. MEdia \& ENT. L.J. 109, 116 (2017).

95. E.g., Jeanne C. Fromer, Patent Disclosure, 94 IowA L. Rev. 539, 548-50 (2009).

96. MPEP, supra note 55, $\S 2164.02$ ("Compliance with the enablement requirement ... does not turn on whether an example is disclosed . . lack of working examples or lack of evidence that the claimed invention works as described should never be the sole reason for rejecting the claimed invention on the grounds of lack of enablement.").

97. Janet Freilich, supra note 9, at 31 (finding that approximately $50 \%$ of chemistry and life sciences patents contain experiments, and noting that the true number of patents containing experiments is likely higher than this figure).

98. 35 U.S.C. $\S \S 101,112$ (a)-(b) (2012).

99. 35 U.S.C. $\S 101$. 
could make and use the invention without "undue experimentation," 100 and (3) a description of the invention in terms sufficiently complete to demonstrate that the inventor was in "possession" of the invention. ${ }^{101}$

Experiments satisfy these requirements in several ways. An experiment showing that a molecule treats a particular disease is evidence that the molecule is useful. ${ }^{102}$ The experiment also describes the step-by-step process of making or using the invention and is, therefore, essentially an instruction manual to others who want to make or use the invention. ${ }^{103}$ Finally, the experiment shows that the patentee made the invention, which helps demonstrate possession. ${ }^{104}$

Once a patent is granted, it is presumed valid, meaning that it is presumed useful, enabled, and adequately described. ${ }^{105}$ As a practical matter, this means that any experiments used to prove utility, enablement, and written description are also presumed to work.

100. 35 U.S.C. § 112; In re Wands, 858 F.2d 731, 737 (Fed. Cir. 1988). The enablement requirement pushes the Constitutional mandate that patents "promote the progress of science" by ensuring that patents disclose enough information that others can build on the invention. AK Steel Corp. v. Sollac, 344 F.3d 1234, 1244 (Fed. Cir. 2003) ("[A]s part of the quid pro quo of the patent bargain, the applicant's specification must enable one of ordinary skill in the art to practice the full scope of the claimed invention.").

101. 35 U.S.C. § 112; Capon v. Eshhar, 418 F.3d 1349, 1357 (Fed. Cir. 2005).

102. Examiners will not ordinarily challenge an applicant's statement of utility. In re Langer, 503 F.2d 1380, 1391 (C.C.P.A. 1974). However, an applicant's case for utility is stronger if the applicant can show experimental evidence that the invention is useful for the stated purpose. The U.S. Patent and Trademark Office (PTO) has rejected applications where the patent provides only general statements of utility without experiments. See, e.g., In re Wright, 999 F.2d 1557, 1560 (Fed. Cir. 1993) (finding that, in the absence of experimental evidence that a vaccine against RNA viruses would work, there was no evidence that the applicant's invention would be useful to create such vaccines); Ex parte Sudilovsky, $1991 \mathrm{WL}$ 332566 , at $* 6$ (B.P.A.I. 1991) (rejecting the application because it provided only general statements of utility without experiments to back them up.).

103. Experiments are not strictly necessary to show enablement. MPEP, supra note 55, § 2164.02. However, the number of experiments present in the patents is a formal factor in the enablement analysis. See Wands, 858 F.2d at 737.

104. The Federal Circuit has acknowledged that "the term 'possession' . . has never been very enlightening." Ariad Pharm., Inc. v. Eli Lilly and Co., 598 F.3d 1336, 1351 (2010). However, the doctrine is generally interpreted as requiring scientists to be able to read the patent and understand that the patentee actually invented the claimed invention. Hologic, Inc. v. Smith \& Nephew, Inc. 884 F.3d 1357, 1358 (Fed. Cir. 2018). Experiments are not necessary to satisfy the written description requirement, but they can help. See, e.g., Wyeth v. Abbott Labs., 2012 WL 175023, at *8 (D.N.J. 2012), aff'd Wyeth \& Cordis Corp. v. Abbott Labs., 720 F.3d 1380 (Fed. Cir. 2013). In Wyeth, the court invalidated a patent for lack of written description because the inventors claimed to have invented a method of treating a condition by administering rapamycin rectally or transdermally, but the inventors had not tried those methods of administration, nor did they know if rectal or transdermal administration would work, and rapamycin had never been administered by those routes by anyone else when the patent was filed. $I d$. The court specifically cited the lack of experiments as a reason for finding inadequate written description. Id.

105. 35 U.S.C. $\S 282$ (2012). 


\section{Incentives and Disincentives for Replicability}

One driver of the irreplicability crisis in the scientific literature is that academic scientists do not fully internalize the cost of irreplicable results, incentivizing poor experimental technique. ${ }^{106}$ A second cause of irreplicability in science is the inability of peer reviewers to put sufficient time and energy into the process to catch irreplicability. ${ }^{107}$ These two factors could look very different in patents. In this Section, I discuss the incentives and abilities of patentees and patent examiners to avoid and catch irreplicable experiments.

\section{a. Patentee Incentives}

Patentees pay tens to hundreds of thousands of dollars to obtain a patent. ${ }^{108}$ If the patented technology does not work, the patentee may not recuperate that cost. Companies filing patents therefore presumably do internalize the cost of irreplicability, suggesting that there is less incentive for patentees to file patents without designing experiments to ensure that the invention works.

In practice, however, patentee incentives may be closer to academic incentives. First, many academic scientists are also patentees. ${ }^{109}$ But even industry patentees have incentives for irreplicability. Companies increasingly reward scientists whose work translates into a patent. The reward is for the patent itself, not for the underlying science. A survey by the American Intellectual Property Law Association reported that $60 \%$ of biotechnology and pharmaceutical companies pay bonuses for employee inventors who file a patent application. ${ }^{110}$ This incentivizes the filing of many patents, but not necessarily the filing of high-quality patents.

If individual inventors do not have an incentive to file replicable patents, surely the companies paying for patent filing do? Perhaps not. There is a growing body of literature suggesting that pure numbers of patents are valuable, even if the contents

106. Supra notes 76-81 and accompanying text.

107. E.g., Luke Oakden-Rayner, Andrew L. Beam \& Lyle J. Palmer, Medical Journals Should Embrace Preprints to Address the Reproducibility Crisis, 47 INT'L J. EPIDEMIOLOGY 1, 2 (2018); Roger Peng, The Reproducibility Crisis in Science: A Statistical Counterattack, 12 SignifiCANCE 30, 30 (2015).

108. Filing a patent in the United States can cost between $\$ 10,000$ and $\$ 20,000$. Lemley, supra note 38, at 1499; Gene Quinn, The Cost of Obtaining a Patent in the US, IP WATCHDOG (Apr. 4, 2015), http://www.ipwatchdog.com/2015/04/04/the-cost-of-obtaining-a-patent-inthe-us/id=56485 [https://perma.cc/YE64-V3TN]. Filing a patent internationally can cost many hundreds of thousands of dollars, depending on the number of countries in which patent protection is desired. Anthony de Andrade \& Venkatesh Viswanath, Estimating the Cost for Filing, Obtaining and Maintaining Patents Across the Globe, IP WATCHDOG (Aug. 28, 2016), https:/www.ipwatchdog.com/2016/08/28/cost-filing-obtaining-maintaining-patents/id $=72336 /$ [https: $/ /$ perma.cc $/$ PWX3-VU22].

109. Bhaven N. Sampat, David C. Mowery \& Arvids A. Ziedonis, Changes in University Patent Quality After the Bayh-Dole Act: A Re-Examination, 21 InT'L J. INDUS. ORG. 1371, 1372 (2003).

110. Soonhee Jang, Inventor Compensation in the U.S. (2013) (PowerPoint on file with the Indiana Law Journal). 
of those patents are not useful. ${ }^{111}$ Though this literature relates predominantly to patents in the high-tech fields, the concepts apply to some extent in biomedical patenting as well. ${ }^{112}$

Ultimately, industry patentees may have more incentive to ensure replicability than their academic counterparts. However, the incentive story is complex, and it is an empirical question that I investigate in Part II.

\section{b. Examiner Incentives}

It is hard to ask peer reviewers-who are uncompensated and busy- to carefully investigate the likely replicability of a scientific article. By contrast, examinersthough also busy - are paid to carefully review patents. ${ }^{113}$ Thus, even if patentees are not inherently incentivized to care about replicability, examiners could create such an incentive by rejecting patents containing irreplicable experiments.

The evidence on whether examiners assess the quality of experiments is mixed. First, it is well established that the applicant does not have to show utility as a matter of statistical certainty ${ }^{114}$ Further, as a practical matter, the PTO does not need to evaluate statistics at all, since examiners reject applications for lack of credible utility only when the invention could not possibly work. ${ }^{115}$ The PTO acknowledges that these situations are "rare." 116

111. See, e.g., Colleen V. Chien, From Arms Race to Marketplace: The Complex Patent Ecosystem and Its Implications for the Patent System, 62 Hastings L.J. 297, 321 (2010); Stuart J. H. Graham \& Ted Sichelman, Why Do Start-Ups Patent?, 23 Berkeley Tech. L.J. 1063, 1082 (2008); David H. Hsu \& Rosemarie H. Ziedonis, Patents as Quality Signals for Entrepreneurial Ventures, 2006 ACAD. MGMt. Best PAPER Proc. 1, 2 (2006), http://www.management.wharton.upenn.edu/hsu/inc/doc/2015/11.pdf

[https://perma.cc/K6KU-9DCV]; Clarisa Long, Patent Signals, 69 U. CHI. L. REV. 625, 626 (2002); Gideon Parchomovsky \& R. Polk Wagner, Patent Portfolios, 154 U. PA. L. ReV. 1, 4 (2005); David L. Schwartz, On Mass Patent Aggregators, 114 Colum. L. Rev. Sidebar 51, 56 (2014); R. Polk Wagner, Understanding Patent-Quality Mechanisms, 157 U. PA. L. ReV. 2135, 2157 (2009).

112. One way in which large numbers of patents can be useful is in certain monetization strategies used by non-practicing entities. While these are mainly associated with the hightech industry, they can also appear in the life sciences. See, e.g., Robin Feldman \& Nicholson W. Price II, Patent Trolling Why Bio \& Pharmaceuticals Are at Risk, 17 StAn. TeCH. L. ReV. 773, 785-90 (2014).

113. Mark Lemley, Doug Lichtman \& Bhaven Sampat, What to Do about Bad Patents?, REG., Winter 2005-06, at 10, 10 (explaining that examiners spend an average of eighteen hours examining each patent, which may not be enough to catch bad patent applications).

114. Nelson v. Bowler, 626 F.2d 853, 856 (C.C.P.A. 1980) ("Bowler argues that the . . tests are inconclusive showings of pharmacological activity since confirmation by statistically significant means ... occurred after the critical date [i.e. too late]. But a rigorous correlation is not necessary where the test for pharmacological activity is reasonably indicative of the desired response.").

115. MPEP, supra note 55, $\S 2107.01$ (II). Generally, this arises in the context of a machine that is physically impossible, such as a perpetual motion machine. See, e.g., Newman v. Quigg, 877 F.2d 1575, 1582 (Fed. Cir. 1989) (upholding the PTO's decision not to grant a patent on a perpetual motion machine).

116. MPEP, supra note 55, $\S 2107.01($ II). Further, even if an examiner wanted to examine 
However, there are hints in the doctrine that the PTO values reliability of data (which might include replicability) at least to some extent. First, any data used to show that in vitro experiments are likely to have in vivo utility must be "statistically relevant," 117 though neither the PTO nor the courts have provided any additional detail on what exactly that means. ${ }^{118}$ Second, the PTO instructs examiners to assess whether the provided data is "reasonably predictive of the asserted utility." 119 Examiners should look at factors that are somewhat similar to those thought to promote replicability, for example, "test parameters, choice of animal . . relative significance of the data provided" and others. ${ }^{120}$ In addition, though the PTO does not instruct examiners to consider the quality of the experiment or its statistical validity, ${ }^{121}$ examiners do so at least on occasion. For example, in Application No. $10 / 628,102$, the examiner rejected the application for lack of enablement and wrote that while the invention was tested on patients, "[i]t is noted there were no control groups shown." 122

While these examples suggest that examiners care about replicability, they are isolated incidents and not representative of PTO policy. Further, even if examiners are looking out for poorly designed experiments and results that might not be replicable, they may not have the expertise to identify these experiments. ${ }^{123}$ As with

experimental quality closely, there is no time to do so; examiners spend an average of just eighteen hours examining each patent. Robert P. Merges, As Many as Six Impossible Patents Before Breakfast: Property Rights for Business Concepts and Patent System Reform, 14 BERKELEY TECH. L.J. 577, 590 (1999).

117. MPEP, supra note 55, § 2107.03(I).

118. The term "statistically relevant" is used in only four patent cases (as of June 2018), and none elaborate on the term beyond quoting the MPEP. In re ' 318 Patent Infringement Litigation, 583 F.3d 1317, 1326 n.10 (Fed. Cir. 2009); CreAgri, Inc. v. Pinnaclife, Inc., No. 11-CV-6635-LHK, 2013 WL 6673676, at*18 (N.D. Cal. 2013); Eli Lilly \& Co. v. Actavis Elizabeth LLC, 731 F. Supp. 2d 348, 382 n.15 (D.N.J. 2010), aff'd in part, rev'd in part, 435 F. App'x 917 (Fed. Cir. 2011); Eli Lilly \& Co. v. Actavis Elizabeth LLC, 676 F. Supp. 2d 352, 369 n.13 (D.N.J. 2009), aff'd in part, rev'd in part, 435 F. App'x 917 (Fed. Cir. 2011).

119. MPEP, supra note 55, $§ 2107.03$ (III) (citing Ex parte Maas, 9 USPQ2d 1746 (B.P.A.I. 1987); Ex parte Balzarini 21 USPQ2d 1892 (B.P.A.I. 1991)).

120. MPEP, supra note 55, §2107.03(III).

121. Statistical validity is not mentioned in the instructions for examiners. MPEP, supra note $55, \S 2164$.

122. Non-Final Rejection, U.S. Patent Application No. 10/628,102 at 6 (May 4, 2004). The patent was later granted as U.S. Patent No. 6,987,093 (filed July 25, 2003) (issued Jan. 17, 2006). Similarly, the examiner rejected Application No. 12/672,963 for lack of enablement, stating that "patients with progressive disease were the only group with a disease assessment used in the comparison. Therefore, it is unpredictable whether determining and comparing the level of the PSPH gene expression can be used to predict that a patient will have any type of response to [the claimed invention]." In another example, an examiner rejected Application No. 12/324,198 for lack of enablement because the application claimed a particular type of soybean seed and "[s]ince the seed claimed is essential to the claimed invention, it must be obtainable by a repeatable method set forth in the specification or otherwise be readily available to the public." Non-Final Rejection, U.S. Patent Application No. 12/324,198 at 3 (Oct. 4, 2010) (emphasis added). The patent was granted after a sample of the seed was deposited with the PTO. U.S. Patent No. 8,035,000 (issued Oct. 11, 2011).

123. Ouellette, supra note 37, at 1828; see also Ronald J. Mann, The Idiosyncrasy of Patent 
patentee incentives, examiner incentives for enforcing replicability are mixed, suggesting the need for further study to determine how the PTO assesses experimental quality.

Irreplicable experiments harm the objectives and functioning of the patent system. Further, as a theoretical matter, it is plausible that there are many irreplicable experiments in patents. The topic of irreplicable experiments in patents therefore merits more careful study.

\section{MEASURING IRREPLICABILITY IN PATENTS: AN EMPIRICAL STUDY}

Replicable studies are vital to the transmission of scientific knowledge. Patents, as documents expected to empower the transmission of scientific knowledge, ought to be replicable. While the theoretical case for why patents should be replicable is strong, the doctrine implementing standards of replicability is not. Thus, it is unclear whether experiments disclosed in patents are replicable. It is important for scientists to know whether experiments disclosed in patents are replicable so that scientists can allocate proper weight to information learned from patents. It is also important for policy makers to know whether experiments disclosed in patents are replicable because, if replicability rates are low, it may be worthwhile to make policy changes to improve replicability or adapt to its lack thereof. ${ }^{124}$ Studies of replicability in experiments published in scientific journals abound, and the topic has generated enormous debate. ${ }^{125}$ There are no empirical studies on replicability in the context of patents, a gap which this Article seeks to fill.

\section{A. Methodology}

\section{Testing Replicability}

Replicability can be tested directly by attempting to redo an experiment in a lab. However, this is sufficiently expensive that it is rarely done, and has never been done for large numbers of experiments. ${ }^{126}$ Instead, much of the literature on the replicability crisis in science has relied not on experimental replication, but on studies of the theoretical bases for irreplicability. ${ }^{127}$ In particular, many replication studies look at the methodology used to conduct experiments and assess whether the methodology is sufficiently well designed and reported that there is even a chance that the experiment will be replicable. ${ }^{128}$

Examiners: Effects of Experience and Attrition, 92 TEX. L. REV. 2149, 2163 (2014).

124. See infra Sections III.A., III.B.

125. See supra Section I.A.

126. For example, a program called the Reproducibility Initiative is seeking to replicate fifty experiments at a cost of $\$ 1.3$ million. Trouble at the Lab, ECONOMIST (Oct. 18, 2013), https://www.economist.com/briefing/2013/10/18/trouble-at-the-lab [https://perma.cc/UMR4V6CK].

127. See supra Section I.A.

128. See infra note 137. 
Instead of testing replication directly, this method tests whether the methodological predicates for replicability are present. ${ }^{129}$ As I explain in more detail below, I score the methodological quality of experiments in patents as a proxy for whether the experiments are likely to be replicable.

The intuition behind this proxy is that poor methodology often leads to incorrect - and therefore irreplicable - findings. This has been proven repeatedly in the scientific literature. ${ }^{130}$ For instance, a study that does not take measures to reduce sources of bias, such as randomization or blinding, is more likely to be irreplicable. ${ }^{131}$ Randomization ensures that characteristics are balanced across the treatment and control groups, making it more likely that a difference seen between the groups is the result of the treatment, rather than a confounding variable. ${ }^{132}$ Similarly, if a study does no statistical analysis, any difference between the treatment and control groups may be attributable to some chance characteristic about the sample, rather than a true effect that will be replicable in a different group. ${ }^{133}$

Methodology is not a perfect proxy for replicability. First, it relies on the investigator's report of methodology, so it is possible for a study to be done very well but to omit important methodological details in the reporting so that the study appears to be done badly. Second, it is possible for a study to be poorly conducted, and yet also be correct — bad methodology decreases the chance of being correct but does not eliminate it.

However, the use of methodological quality as a proxy for replicability has been well validated in the scientific literature. ${ }^{134}$ For example, after Glenn Begley and Lee

129. Id.

130. Id.

131. See, e.g., Landis et al., supra note 83, at 188.

132. See, e.g., Hyuna Yang, Christina A. Harrington, Kristina Vartanian, Christopher D. Coldren, Rob Hall \& Gary A. Churchill, Randomization in Laboratory Procedure is Key to Obtaining Reproducible Microarray Results, PLOS ONE, Nov. 2008, at 9.

133. See, e.g., Lemuel A. Moye, Statistical Reasoning in Medicine 127 (2006).

134. See, e.g., Kenneth R. Hess, Statistical Design Considerations in Animal Studies Published Recently in Cancer Research, 71 CANCER RES. 625, 625 (2011) (reviewing 100 articles to determine whether key methodological predicates were present and finding that while "[g]ood statistical design is one hallmark of meritorious research . . clearly, the use of essential statistical design features . . . has room for improvement."); Carol Kilkenny, Nick Parsons, Ed Kadyszewski, Michael F. W. Festing, Innes C. Cuthill, Derek Fry, Jane Hutton \& Douglas G. Altman, Survey of the Quality of Experimental Design, Statistical Analysis and Reporting of Research Using Animals, PLOS ONE, Nov. 2009, 1, 9 (reporting a study of 271 publications and finding that although "[a]ccurate and transparent reporting is . . . vital to allow the reader to assess . . . the reliability and importance of the scientific findings," they "provide evidence that many peer reviewed, animal research publications fail to report important information regarding experimental and statistical methods"); J. Pildal, A. Hróbjartsson, K.J. Jørgensen, J. Hilden, D.G. Altman \& P.C. Gøtzsche, Impact of Allocation Concealment on Conclusions Drawn From Meta-Analyses of Randomized Trials, 36 InT'L J. EPIDEMIOLOGY 847, 847-48 (2007); see also Vik Bebarta, Dylan Luyten \& Kennon Heard, Emergency Medicine Animal Research: Does Use of Randomization and Blinding Affect the Results? 10 ACAD. EMERGENCY MED. 684, 686 (2003); Malcolm R. Macleod, H. Bar van der Worp, Emily S. Sena, David W. Howells, Ulrich Dirnagl \& Geoffrey A. Donnan, Evidence for the Efficacy of NXY-059 in Experimental Focal Cerebral Ischaemia is Confounded by Study Quality, 39 Stroke 2284, 2287 (2008); Oswald Steward, Phillip G. Popovich, W. Dalton Dietrich \& 
Ellis's attempt to replicate experiments directly found many were not replicable, Begley and Ellis reported that, for experiments that could be replicated "authors had paid close attention to [methodology] . . and describ[ed] the complete data set." 135 On the other hand, a host of methodological detail was missing in the experiments that could not be replicated. ${ }^{136}$

In addition, articles finding that many studies have poorly reported methodology are frequently cited as evidence of irreplicability ${ }^{137}$ Further, multiple studies have found that experiments with poor methodology tend to find larger effect sizes than experiments with good methodology. ${ }^{138}$ This suggests that experiments with bad methodology are skewed towards seeing an effect where no effect, or a smaller effect, actually exists. Moreover, many organizations advocating for improved replicability begin with efforts to improve the reporting of methodology. ${ }^{139}$

As a proxy for replicability, observing the methodological quality of studies likely underreports irreplicability. A study that has well-reported methodology will not necessary be replicable. Thus, the approach used here creates a floor for replicability: whatever the number of patents found to have insufficient methodological quality for

Naomi Kleitman, Replication and Reproducibility in Spinal Cord Injury Research, 233 Experimental Neurology 597, 597 (2012); H. Bart van der Worp \& Malcolm R. Macleod, Preclinical Studies of Human Diseases: Time to Take Methodological Quality Seriously, 51 J. Molecular \& Cellular Cardiology 449, 449 (2011); Hanna M. Vesterinen, Emily S. Sena, Charles Ffrench-Constant, Anna Williams, Siddharthan Chandran \& Malcom R. Macleod, Improving the Translational Hit of Experimental Treatments in Multiple Sclerosis, 16 Multiple SClerosis J. 1044, 1048 (2010).

135. Begley \& Ellis, supra note 1, at 532 .

136. Id.

137. See, e.g., David Baker, Katie Lidster, Ana Sottomayor \& Sandra Amor, Two Years Later: Journals Are Not Yet Enforcing the ARRIVE Guidelines on Reporting Standards for Pre-Clinical Animal Studies, PLoS Biology, Jan. 2014, at 1 ("Inadequate reporting of key aspects of experimental design may reduce the impact of studies and could act as a barrier to translation by preventing repetition ...."); Landis et al., supra note 83, at 187 ("Several recent articles, commentaries, and editorials highlight that inadequate experimental reporting can result in such studies being un-interpretable and difficult to reproduce."); David Moher, Iveta Simera, Kenneth F. Schulz, John Hoey \& Douglas G. Altman, Helping Editors, Peer Reviewers and Authors Improve the Clarity, Completeness and Transparency of Reporting Health Research, 6 BMC MED. 13, 13 (2008) (opening the article with the heading title "The reporting of medical research is not clear and transparent: an unacceptable scandal" based on citations to articles finding poor methodological reporting).

138. Evelien D.M. Rooke, Hanna M. Vesterinen, Emily S. Sena, Kieren J. Egan \& Malcolm R. Macleod, Dopamine Agonists in Animal Models of Parkinson's Disease, 17 PARKINSONISM \& RELATED DiSORDERS 313, 319 (2011) (noting that "reported efficacy fell as reported study quality increased"); Emily Sena, H. Bart van der Worp, David Howells \& Malcolm Macleod, How Can We Improve the Pre-Clinical Development of Drugs for Stroke? 30 TRENDS IN NEUROSCI. 433, 433 (2007) (noting that "study-quality and publication bias have substantial effects on published estimates of drug efficacy"); Vesterinen et al., supra note 134, at 1045 ("[S]tudies reporting measures to avoid bias (random allocation to group and blinded assessment of outcome, both important indicators of internal validity) give substantially lower estimates of efficacy than studies that do not report such measures.").

139. Baker et al., supra note 137, at 1; Landis et al., supra note 131, at 188; Moher et al., supra note 137 , at 13 . 
replicability, the true number of irreplicable experiments in patents is probably higher.

\section{Checklist for Replicability}

To assess whether experiments in patents report sufficient methodological detail to be replicable, I use a checklist from the journal Nature. ${ }^{140}$ Although Nature did not generate this checklist specifically to test for replicability, the checklist was designed as a bulwark against irreplicable studies. ${ }^{141}$ Nature explains that:

This non-exhaustive [check]list summarizes several elements of methodology that are frequently poorly reported. Inconsistent reporting may lead to incorrect interpretation of results and a lack of reproducibility. To improve the transparency and the reproducibility of published results, we ask that authors include in their manuscripts relevant details about these elements of their experimental design. During peer review, authors confirm via the Reporting Checklist for Life Sciences Articles that this information is reported. ${ }^{142}$

For each experiment in my sample, I reviewed the experiment to determine if it contains the information in Table 1 below. In creating this table, I excluded elements of the Nature checklist that were specific to certain types of experiments. ${ }^{143}$

140. Nature Publ'G Grp., Reporting Life Sciences Research (2015), https://www.nature.com/authors/policies/reporting.pdf [https://perma.cc/BCG3-7MYT]. Though there are many checklists available, I selected this list because it is general (rather than focusing on a specific type of experiment) and relatively undemanding as compared to other, more detailed checklists. It is therefore an appropriate choice for establishing a floor on replicability.

141. Id. at i.

142. Id.

143. Specifically, I excluded elements involving antibodies, cell lines, human clinical trials, and electrophoresis and gel data. 
Table 1: Nature Checklist

\begin{tabular}{|c|c|c|}
\hline Information on: & Explanation & Example $^{144}$ \\
\hline Sample Size & $\begin{array}{l}\text { The number of samples } \\
\text { used. }{ }^{145}\end{array}$ & $\begin{array}{l}\text { " } 50 \text { female } \mathrm{C} 57 / \mathrm{BL} \text { mice } \ldots \text { were } \\
\text { divided into } 5 \text { groups of } 10 \text { mice } \\
\text { per group." } 146\end{array}$ \\
\hline Randomization & $\begin{array}{l}\text { Whether samples were } \\
\text { randomly assigned to } \\
\text { experimental groups. }{ }^{147}\end{array}$ & $\begin{array}{l}\text { "When the tumors reached a } \\
\text { volume of approximately } 200 \\
\mathrm{~mm}^{3} \text { mice were randomized into } \\
\text { groups . . ." "148 }\end{array}$ \\
\hline Blinding & $\begin{array}{l}\text { Whether investigators } \\
\text { were unaware of } \\
\text { sample group } \\
\text { allocation. }{ }^{149}\end{array}$ & $\begin{array}{l}\text { "The study was done blindly, } \\
\text { meaning that the treatment and } \\
\text { the preparation of the drugs were } \\
\text { conducted by separate } \\
\text { individuals." } 150\end{array}$ \\
\hline Replication & $\begin{array}{l}\text { Whether an experiment } \\
\text { was repeated. }{ }^{151}\end{array}$ & $\begin{array}{l}\text { "To confirm that indeed } \\
\text { immunization with CD86- } \\
\text { transfected tumor cells was } \\
\text { associated with increased } \\
\text { expression of CD200, we } \\
\text { repeated the study ...." } 152\end{array}$ \\
\hline Statistical Tests & $\begin{array}{l}\text { Whether statistical tests } \\
\text { are used. }{ }^{153}\end{array}$ & $\begin{array}{l}\text { Significance was calculated with } \\
\text { "Student's } t \text { test or one-way or } \\
\text { two way ANOVA" using a } \\
\text { standard software package } \\
\text { (Origin) with } p<0.05 .{ }^{154}\end{array}$ \\
\hline
\end{tabular}

144. Examples in this column are derived from my data, not from the Nature checklist.

145. This was coded as present if there was an exact or estimated number of animals. Sample size was also coded as present if the number of animals per group was stated, even if the number of groups was not stated.

146. U.S. Patent No. 9,629,898 ex. 4 (filed Dec. 16, 2014).

147. This was coded as present if the experiment specified whether or not there was randomization. As a practical matter, all experiments that discussed randomization did so in the context of stating that there was randomization; no experiments stated that there was not randomization.

148. U.S. Patent No. 8,901,136 ex. 139 (filed June 6, 2013).

149. This was coded as present if the experiment specified whether or not there was blinding. As with randomization, all experiments that discussed blinding did so in the context of stating that there was blinding.

150. U.S. Patent No. 7,396,860 ex. 1 (filed Nov. 13, 2003).

151. This was coded as present if the experiment specified whether or not there were replicates. As a practical matter, all experiments that discussed replication did so in the context of stating that there was replication.

152. U.S. Patent No. 7,452,536 ex. 8 (filed May 25, 2007).

153. This included any sort of statistical analysis whatsoever, including reporting measures of variance such as standard deviation, standard error, or confidence intervals.

154. U.S. Patent No. 8,557,788 col. 84 (filed July 11, 2012). 


\section{Sample}

Many patents contain experimental protocols and data, which are called "examples." 155 I compiled a database of all examples in applications filed and patents granted between 2001 and 2016. I did so by writing an algorithm that identified the examples section of the patent and then broke the section down into individual examples. $^{156}$

Examples in patents come in two varieties: working and prophetic examples. Working examples describe experiments that have actually been conducted whereas prophetic examples describe experiments that are merely hypothetical and have not actually been carried out. ${ }^{157}$ Prophetic examples cannot be written in the past tensedoing so is inequitable conduct and can result in the patent being unenforceable. ${ }^{158}$ It is therefore conventional to write prophetic examples in the present or future tense and working examples in the past tense. ${ }^{159}$

For this project, I selected only working examples by limiting my sample to examples written in the past tense. ${ }^{160}$ While issues of the veracity of prophetic examples are interesting, the term "replicability" as it is conventionally used requires that the experiment have already been done once, which is applicable only to working examples. I associated each study with a random number and reviewed studies beginning with the lowest random number and proceeding upwards. I reviewed only one experiment per patent. ${ }^{161}$ Where possible I was blinded. ${ }^{162}$

155. E.g., MPEP, supra note 55, § 2164.02 .

156. Full details about the database can be found at Freilich, supra note 9, at 26-28. Patent data was obtained from the USPTO's Grant Full Text Database, hosted by Reed Tech. Reed Tech, USPTO Data Sets: Patent Grant Red Book, USPTO (2017), http://patents.reedtech.com /pgrbft.php [https://perma.cc/TQ7U-FWM2].

157. MPEP, supra note 55, $\S 608.01(\mathrm{p})$; Freilich, supra note 9 , at 9.

158. Hoffmann-La Roche, Inc. v. Promega Corp., 323 F.3d 1354, 1363 (Fed. Cir. 2003); see also Purdue Pharma. L.P. v. Endo Pharm. Inc., 438 F.3d 1123, 1134 (Fed. Cir. 2006); Novo Nordisk Pharm., Inc. v. Bio-Tech Gen. Corp., 424 F.3d 1347, 1362 (Fed. Cir. 2005).

159. Freilich, supra note 9 , at 14.

160. To ensure that I selected experiments where the elements of the Nature checklist would be methodologically appropriate, I included only studies that had the format "does X treatment affect Y outcome." This excluded $14 \%$ of the sample. I additionally excluded continuations and divisionals. I identified continuations and divisionals by searching for patents that had the same priority date and same original assignee.

161. Where the experiment referenced details in other portions of the patent or was a continuation of a previous experiment, I reviewed those details. Additionally, if the experiment referenced figures, I reviewed those figures, as well as figure legends. If there was a general methodology section outside of a specific experiment, I also reviewed that. Where the patent referenced a study outside the patent, I did not review it. Patents occasionally cite another study as a source of methodology. I chose not to review those outside studies because while the general design of the experiment was taken from that study, details such as sample size would not necessarily be copied from the study.

162. I was blind as to whether a particular experiment was part of a treated group (e.g. an Orange Book listed experiment). I was not blinded for the initial assessment of methodological quality in Section B.1, because it was not possible to blind. 
I further limited the sample to preclinical animal studies. ${ }^{163}$ I made this choice for several reasons. First, animal studies are the penultimate type of experiment conducted by researchers in the life sciences - they precede only human studies. ${ }^{164}$ They are also expensive and must be approved by ethics committees. ${ }^{165}$ Because of these features, they are not done casually, but are instead the result of careful planning and extensive preparation. Second, the replicability crisis in the scientific literature is thought to be most acute in preclinical animal studies. ${ }^{166}$ Studying animal experiments in patents makes it easier to compare the results to the scientific literature.

The example below, from U.S. Patent No. 9,387,199, ${ }^{167}$ illustrates how scoring was conducted. I gave this experiment a score of 2 because it disclosed the sample size and included statistical analysis, but did not mention randomization, blinding, or replicates.

163. To compile a list of animal studies, I selected working examples that contained at least one of the following words: mouse, mice, rat, rats, hamster, hamsters, guinea pig, guinea pigs, rabbit, rabbits, cat, cats, dog, dogs. These words are derived from a National Research Council and Institute of Medicine study reporting the most commonly used laboratory animals. NAT'L Research Council \& Inst. Use Lab. Animals Biomed. \& Behavioral Research, Use of LABORATORY ANimals in BiomedicAl AND BEHAVioRAl RESEARCH 20-21 tbl. 1 (1988). The resulting list was overinclusive because it included studies on, for example, mouse cells or mouse antibodies. This excluded $57 \%$ of the original sample.

164. The Drug Development Process, Food \& DRUg Admin. (2018), https://www.fda.gov/forpatients/approvals/drugs/ [https://perma.cc/FV9Q-6CTV].

165. NAT'L Acad. of Sci., On Being a Scientist: A Guide to Responsible Conduct in RESEARCH 24 (3rd ed. 2009).

166. See, e.g., Francis S. Collins \& Lawrence A. Tabak, NIH Plans to Enhance Reproducibility, 505 NATURE 612, 612 (2014) (footnote omitted) ("Preclinical research, especially work that uses animal models, seems to be the area that is currently most susceptible to reproducibility issues.").

167. U.S. Patent No. 9,387,199 (filed Nov. 12, 2014). 

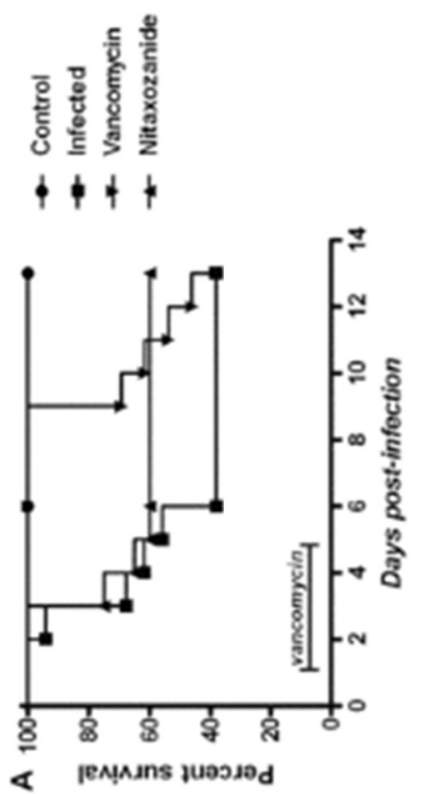

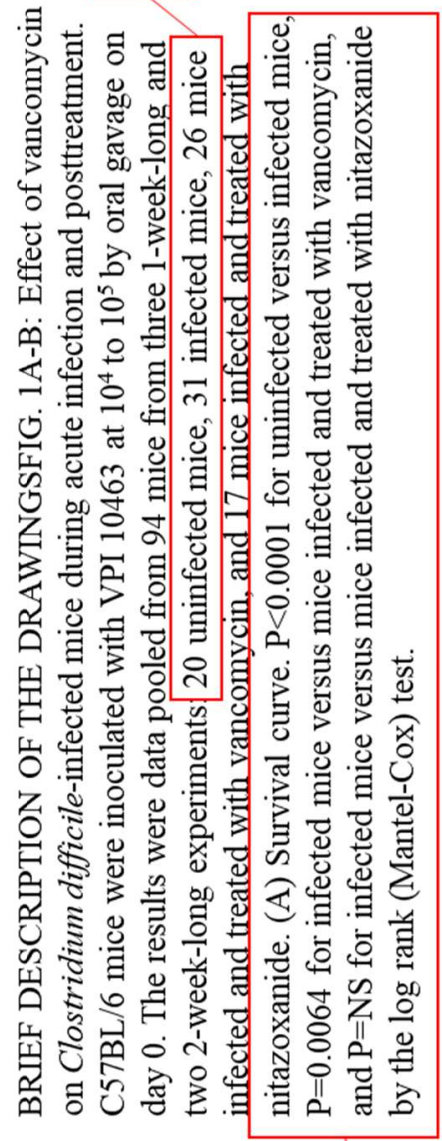

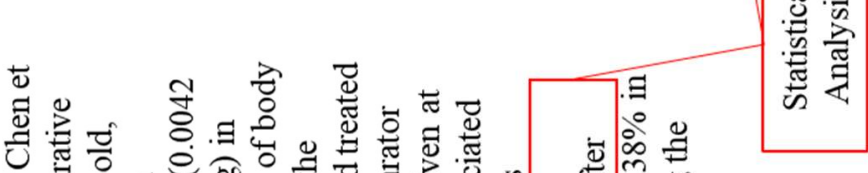

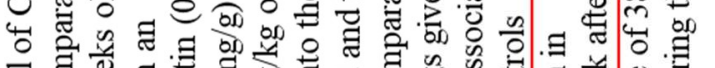

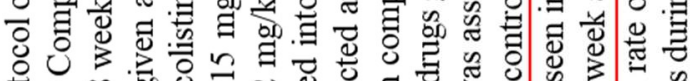

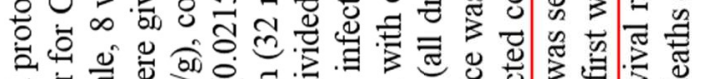
可焉 b0

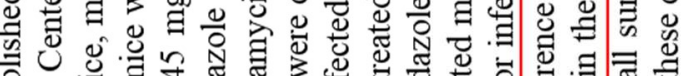

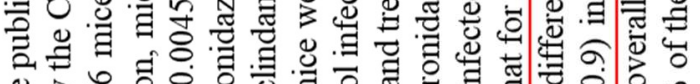

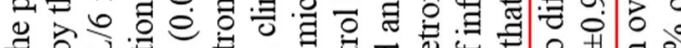

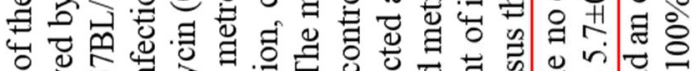

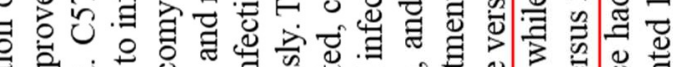

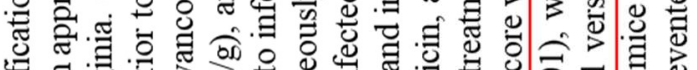

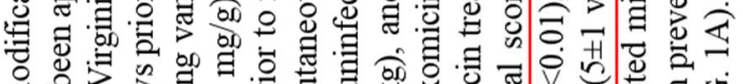

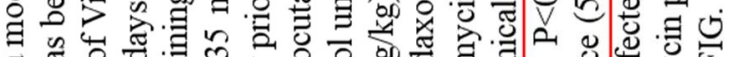

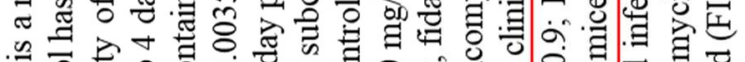

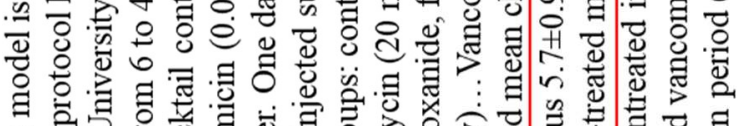

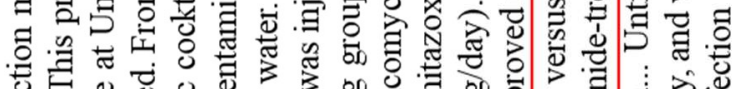
选贯幽.

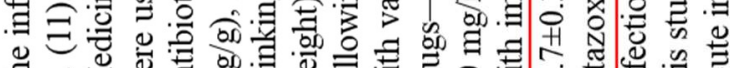

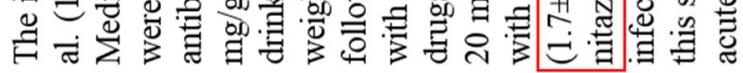




\section{B. Results}

\section{Methodological Quality of Experiments in Patents}

To obtain an overall measure of methodological quality, I determined how many elements of the Nature checklist were disclosed in each experiment, scoring each element of the checklist as a binary (yes/no) variable. ${ }^{168}$ I analyzed 250 randomly selected experiments from granted patents. Because there are five elements in the checklist, the maximum possible score is 5 , and the minimum possible score is 0 . Table 2 shows summary statistics and Figure 1 shows a histogram of scores. The scores ranged from 0 to 4 , with no experiments scoring a perfect 5 . The median score was $1.46 \%$ of experiments included only one of the elements in the Nature checklist.

Table 2: Methodological Scores, Summary Statistics (N=250)

\begin{tabular}{|l|c|}
\hline Mean Score & 1.4 \\
\hline Median Score & 1 \\
\hline Minimum Score & 0 \\
\hline Maximum Score & 4 \\
\hline
\end{tabular}

Figure 1: Histogram of Methodological Scores $(\mathrm{N}=250)$

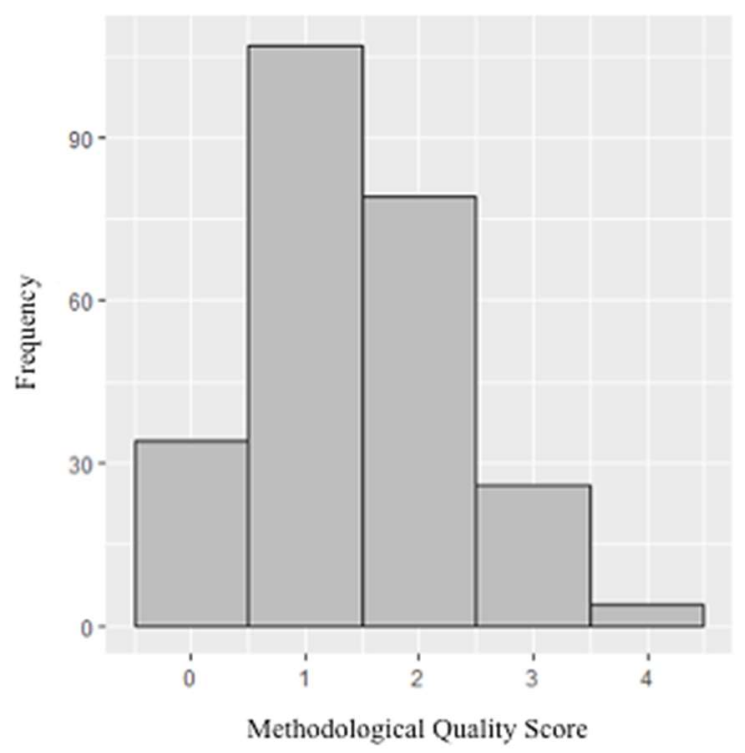

168. For instance, if sample size was disclosed, the experiment was assigned a " 1 " for that variable, if no sample size was disclosed, the experiment was assigned a "0". 
Figure 2 breaks the results out by individual element of the checklist. About $60 \%$ of experiments disclosed the number of animals used in the experiment and about $60 \%$ disclosed some form of statistical analysis. The other checklist elements fared far worse, with $12 \%$ of experiments randomizing, $4 \%$ blinding, and only $2 \%$ disclosing any replicates.

Figure 2: Percent of Experiments in Patents Disclosing Each Element of Nature Checklist $(\mathrm{N}=250)^{169}$

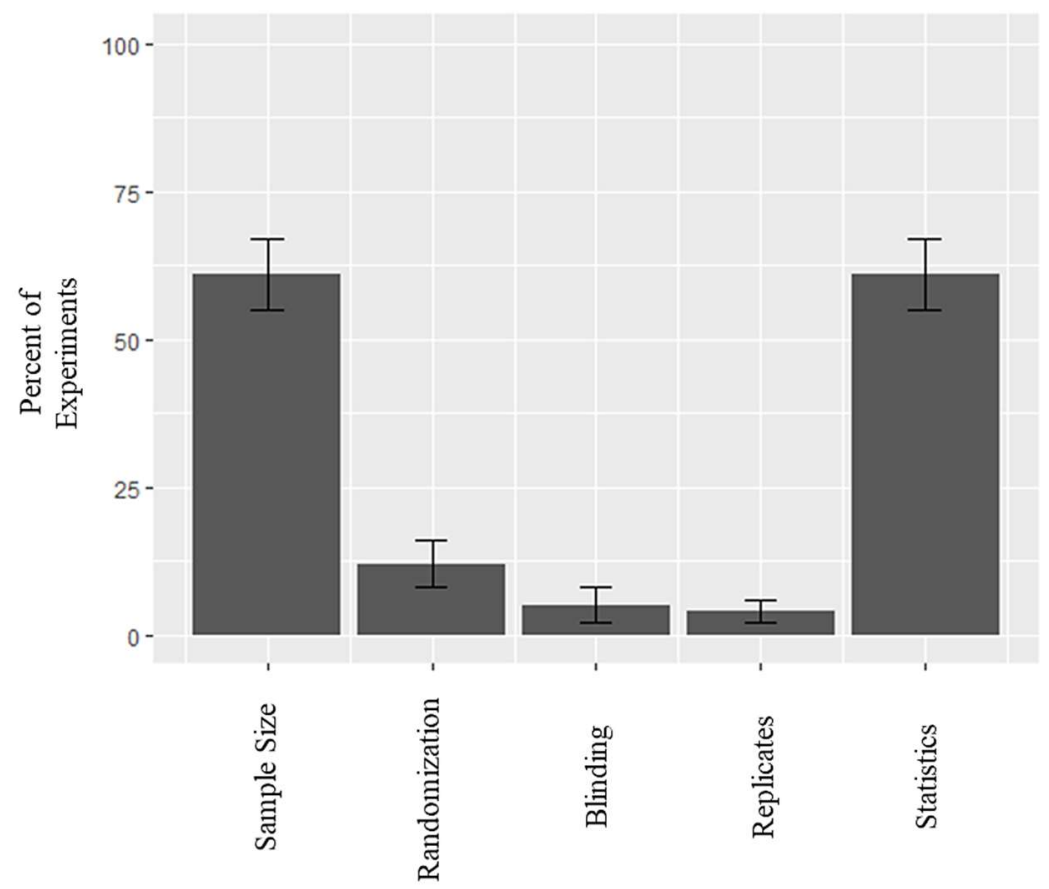

These numbers do not tell us much in isolation. To understand their significance, Table 3 compares the methodological quality of patents to the methodological quality of scientific articles. For each item on the Nature checklist, the item is present less often in patents than in scientific articles. This suggests that replicability in patents is likely also at "crisis" levels. The methodological quality of experiments in scientific articles is associated with unacceptably low rates of replicability - and patents are even worse.

Note that Table 3 presents a range of values for scientific articles, taken from studies of different kinds of biomedical preclinical animal experiments. Multiple studies have reviewed methodological quality in scientific articles, and each study uses a somewhat different approach, a different checklist of items, interprets checklist items in slightly different ways, studies a different population of journal articles, and is done at a different time. Since no one study done on scientific articles

169. Error bars show $95 \%$ confidence intervals. 
reviewed a population that is directly comparable to patents, I chose to present a range of data from many studies. Additionally, since there are many differences between the types of experiments reviewed in the studies of scientific articles and the study of patents, the numbers should be compared as ballpark estimates, rather than as direct comparisons.

Table 3: Comparing Granted Patents $(\mathrm{N}=250)$ and Scientific Articles

\begin{tabular}{|l|l|l|}
\hline & Patents & Scientific Articles (range) ${ }^{\mathbf{1 7 0}}$ \\
\hline Sample Size & $62 \%$ & $70-98 \%$ \\
\hline Randomization & $12 \%$ & $10-22 \%$ \\
\hline Blinding & $5 \%$ & $9-42 \%$ \\
\hline Replicates & $4 \%$ & $\mathrm{~N} / \mathrm{A}^{171}$ \\
\hline Statistics & $63 \%$ & $88-100 \%$ \\
\hline
\end{tabular}

2. Validating the Measure

One challenge with the approach used in this article is that it cannot differentiate between failure to conduct an element such as randomization and failure to report the element. It is possible that patents that do not mention randomization do in fact randomize, but the patent attorney drafting the article does not deem it necessary to include the detail. This underreporting would still be a problem because it means that the reader cannot sort high quality studies from low quality studies. However, it would not necessarily imply that the study is irreplicable. While the scientific literature does find some correlation between poor reporting and irreplicable experiments, ${ }^{172}$ that correlation may not hold for patents, because the norms and expectations for reporting experiments may be quite different in patents.

In this Section, I seek to show that methodological quality as reported in the patent is correlated with the quality of the experiment itself and not merely attributable to drafting conventions.

170. Baker et al., supra note 137, at 4; SeungHye Han, Tolani F. Olonisakin, John P. Pribis, Jill Zupetic, Joo Heung Yoon, Kyle M. Holleran, Kwonho Jeong, Nader Shaikh, Doris M. Rubio \& Janet S. Lee, A Checklist is Associated with Increased Quality of Reporting Preclinical Biomedical Research: A Systematic Review, PLoS ONE, Sept. 2017, at 7; Kilkenny et al., supra note 134, at 4-8; Kimberley H.J. Ting, Catherine L. Hill \& Samuel L. Whittle, Quality of Reporting of Interventional Animal Studies in Rheumatology: A Systematic Review Using the ARRIVE Guidelines, 18 InT'L J. Rheumatic Diseases 488, 493 (2015); Hanna V. Vesterinen, Kieren Egan, Amelie Deister, Peter Schlattmann, Malcolm R. Macleod \& Ulrich Dirnagl, Systematic Survey of the Design, Statistical Analysis, and Reporting of Studies Published in the 2008 Volume of the Journal of Cerebral Blood Flow \& Metabolism, 31 J. Cerebral Blood Flow \& Metabolism 1064, 1067 (2011).

171. None of the aforementioned studies assessed the number of replicates in the scientific articles studied. See supra note 170.

172. E.g., Jenna Wilson, Promoting Reproducibility by Emphasizing Reporting: PLOS ONE's approach, PLOS BLOG (June 14, 2017), http://blogs.plos.org/everyone/2017/06/14 /promoting-reproducibility/ [https://perma.cc/ZR4U-2USF]. 


\section{a. Association with Lawyers and Clients}

If methodological quality as reported in patents is a feature of drafting, rather than of experimental protocol, then particular lawyers should consistently include the same features. By contrast, if methodological quality as reported in patents accurately reflects how the experiment was conducted, then it should vary across lawyers, but the same scientists should consistently include the same features. Essentially, if methodological quality reflects the lawyer's drafting choices, then it should cluster by lawyer, but if methodological quality reflects the scientists' experimental design choices, then it should cluster by client.

Because each lawyer files only a small number of patents, I generated a large sample to test whether methodological quality was associated with lawyers or with clients. To do this, I randomly selected a sample of 7500 granted patents with animal experiments using the methodology described above and eliminated continuations. 6529 patents remained. I then associated each remaining patent with the firm that filed the patent and the original assignee using the PatentsView API provided by the PTO and Google Patents. ${ }^{173}$

For each experiment in my sample, I determined if the experiment was randomized. I use randomization because manually determining a methodology score for thousands of experiments is labor intensive, whereas scoring randomization can be semi-automated, making it feasible for large samples. ${ }^{174}$ Having classified each experiment as randomized or not randomized, I then used Fisher's Exact Tests to test for an association between firm and randomization and between assignee and randomization. I found a significant association between randomization and assignee $(\mathrm{p}<0.001)$, but not between randomization and firm $(\mathrm{p}=0.2)$. This validates the strategy used to measure replicability in this Article because it suggests that the methodology reported in the patent derives primarily from the company conducting the experiment, rather than the lawyer drafting the patent.

173. U.S. Patent and Trademark Office, Why Explore Patent Data?, PATENTSVIEW (2018), http://www.patentsview.org/api/doc.html [https://perma.cc/5BEY-Q3CX]. Due to limitations of the data, I have data for filing firm, but generally not filing attorney. Thus, I assume that patent drafting style within a firm will be consistent. This assumption is reasonable because attorneys within a firm often work together on patent applications, senior attorneys teach junior attorneys in a firm how to draft patents, and many firms have banks of prior work and templates for attorneys to draw on. I also assume that choice of experimental protocols will be comparable within a given assignee, even though the experiment may have been done by different scientists working for that company.

174. To determine if an experiment is randomized, I selected all patents containing the string "random," then created a spreadsheet with the text fifty characters before and after the string "random." I was able to efficiently review these excerpts to determine if the string "random" was used in the context of randomizing samples in an animal experiment. I manually reviewed 100 experiments with the string "random" and my technique categorized the experiment accurately in ninety-six cases. 


\section{b. Patent-Product Link}

To further validate the strategy used to measure replicability herein, I ask whether methodological quality is linked to a real-world characteristic: commercialization. Although a patent can fail to result in a commercialized product for many reasons that are entirely unrelated to replicability, ${ }^{175}$ if a patent does lead to a commercialized product, it suggests that the technology described in the patent works. This is particularly true in the context of pharmaceutical patents, because commercialized drugs must undergo extensive testing before entering the market. ${ }^{176}$ As described below, I find that patents covering commercialized products have better methodological quality scores than matched noncommercialized patents.

In the context of patents covering drug treatments for humans-all patents reviewed for this Article-patents that result in commercialized products are listed in the "Orange Book." The Orange Book, officially titled Approved Drug Products with Therapeutic Equivalence Evaluations, is maintained by the Food and Drug Administration (FDA). ${ }^{177}$ The Orange Book lists patent information for all approved drugs. ${ }^{178}$

I randomly selected 100 animal experiments from Orange Book-listed patents using the same methodology described above. ${ }^{179}$ I matched each experiment with a randomly selected experiment from a non-Orange Book-listed patent with a priority date falling in the same year. ${ }^{180}$ Experiments from Orange Book-listed patents have

175. For instance, a company could run out of funds or a technological advance in a related field could make the patented technology irrelevant. Of particular relevance in the context of pre-clinical animal experiments, an experiment showing that a drug treats a condition in animals could be replicable but still not translate into use in humans.

176. However, not every drug approved by the FDA works. See, e.g., Sherkow, supra note 8 , at 850 .

177. Orange Book Preface, Food \& Drug AdmIn. (Feb. 5, 2018), https://www.fda.gov /drugs/development-approval-process-drugs/orange-book-preface [https://perma.cc/9HEYRV2P].

178. Id.

179. See supra Part II.A. Orange Book-listed patents were derived from the 2017 and 2018 versions of the Orange Book (on file with the author), as well as archived editions of the Orange Book published between 1985 and 2012. C. SCOtT Hemphill \& BHAVEN N. SAMPAT, Nat'l Bureau Econ. Research, Archival Orange Book Patent Data (2013), http://data.nber.org/fda/orange-book/bhaven/documentation_29sep.pdf [https://perma.cc/ P98Z-X6LW]. Hemphill and Sampat's data file is available at http://data.nber.org/fda/orangebook/bhaven/ [https://perma.cc/WC5G-5HC7].

180. Because commercializing a drug tends to be a lengthy process, patents listed in the Orange Book are older on average than patents in my general sample. Matching by priority date is important because there is some evidence that methodological quality of scientific publications is improving over time, and this may be true for patents as well. See, e.g., Oscar Flórez-Vargas, Andy Brass, George Karystianis, Michael Bramhall, Robert Stevens, Sheena Cruickshank \& Goran Nenadic, Bias in the Reporting of Sex and Age in Biomedical Research on Mouse Models, ELIFE, Mar. 2016, at 4 (showing trend over time towards more articles reporting the sex and age of mice used in experiments); Malcolm R. Macleod, Susan Michie, Ian Roberts, Ulrich Dirnagl, Iain Chalmers, John P.A. Ioannidis, Rustam Al-Shahi Salman, An-Wen Chan \& Paul Glasziou, Biomedical Research: Increasing Value, Reducing Waste, 
considerably better methodological scores than experiments from non-Orange Booklisted patents: a mean methodological score of 1.9 as compared 1.4 for matched nonOrange Book-listed patents $(\mathrm{p}<0.001)$.

Figure 3: Mean Methodological Score for Orange Book and Non-Orange Book Listed-Patents $(\mathrm{N}=100)$

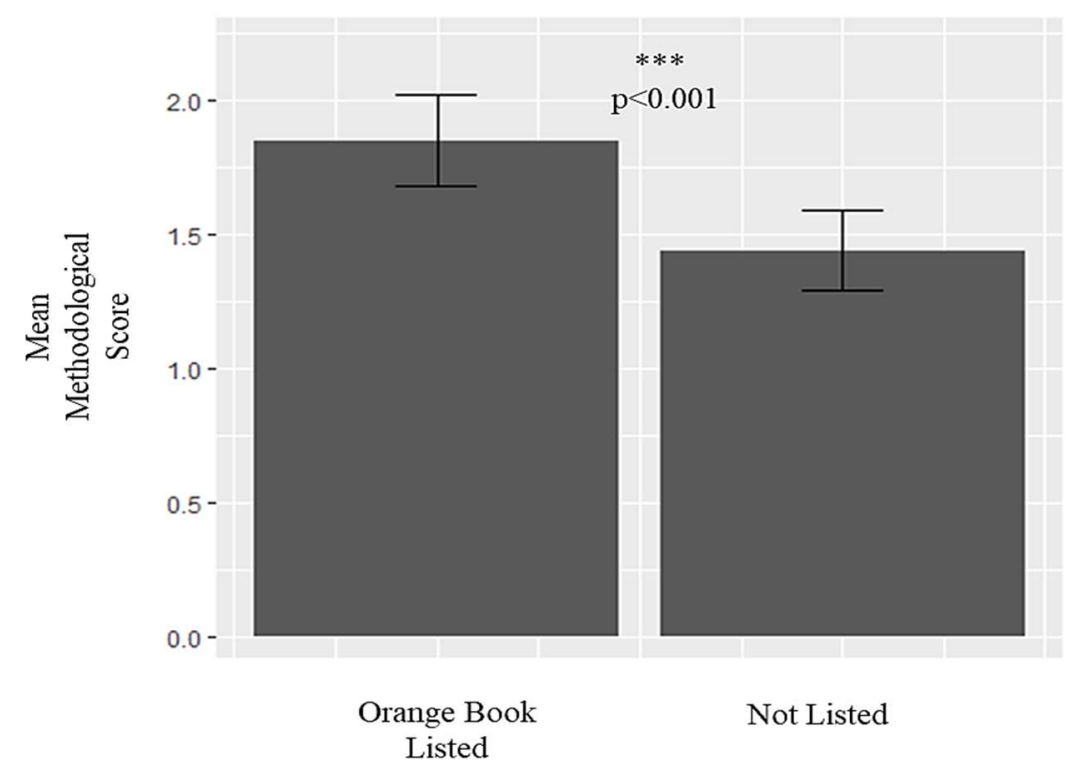

c. Patent-Paper Pairs

Using methodological quality as a proxy for replicability has been validated in the scientific literature. Therefore, if experiments in patents are written like experiments in scientific articles (at least with respect to methodology) then the proxy should also be effective for patents. Patents and papers are thought to often describe the same experiments. ${ }^{181}$ To test the similarity of disclosure of experiments in patents and papers, I matched patents and papers by identity of authors and inventors. ${ }^{182} \mathrm{I}$

383 LANCET 116, 117 (2014) (showing randomization rates increasing over time). But see F. Daniel Ramirez et al., Methodological Rigor in Preclinical Cardiovascular Studies: Targets to Enhance Reproducibility and Promote Research Translation, 2017 CIRCULATION RES. 1920 (finding no increase in blinding or randomization rates over time).

181. Tom Magerman, Bart Van Looy \& Koenraad Debackere, Does Involvement in Patenting Jeopardize One's Academic Footprint? An Analysis of Patent-Paper Pairs in Biotechnology, 44 Res. PoL'y 1702, 1705 (2015); Fiona Murray \& Scott Stern, Do Formal Intellectual Property Rights Hinder the Free Flow of Scientific Knowledge? An Empirical Test of the Anti-Commons Hypothesis, 63 J. Econ. BEHAVIOR \& ORG. 648, 650 (2007).

182. I obtained inventor names from the PTO's PatentsView application programming interface (API), U.S. Patent and Trademark Office, PatentsView, PATENTsVIEw (Aug. 20, 2019), www.patentsview.org, and then searched PubMed for papers filed by authors with the 
reviewed 100 randomly selected patent-paper pairs. There was no significant difference between the methodological scores for papers and for patents (2.2 vs. 2.2, $p=0.4){ }^{183}$ Although patents with paper pairs are not a representative sample of all patents, ${ }^{184}$ the similarities in methodological scores between patents and papers are another piece of evidence that the way that experiments are written in the two different media is sufficiently close that the technique that has been validated for use in the scientific literature should also work well in patents.

\section{PTO Rejections and Patent Grant}

As explained in Section I.B.2, whether PTO examiners assess likelihood of replicability is an empirical question. To address this question, I investigated how methodological quality correlated with rejections from the PTO. If the PTO evaluates likelihood of replicability as part of determining patentability, then applications with poor methodological scores should be more likely to be rejected. Specifically, applications with poor methodological scores might be rejected for one or more of the following reasons:

- Lack of utility because a patent that does not work is not useful. ${ }^{185}$

- Lack of enablement, because an experiment that does not work does not teach others how to make and use the invention. ${ }^{186}$

- Lack of written description, because an experiment that does not work does not prove that the inventor was in possession of the invention. ${ }^{187}$

Such applications might also be less likely to be granted. As described below, there is no correlation between the rejections above and methodological score. ${ }^{188}$ There is also no correlation between likelihood of grant and methodological score. This

same name as the inventor. I included papers only if they covered roughly similar topics to their patent pair. If multiple papers had authors with the same name as a patent's inventors, I selected the paper filed soonest after the priority date of the patent. For each patent in the pair, I randomly selected an experiment from the patent and manually checked to ensure that it was an animal experiment. I then compared the methodology in each patent-paper pair. For pairs where the randomly selected experiment appeared in both patent and paper, I compared methodology for only that experiment. For pairs that did not have an experiment overlap, I compared methodology across the entire patent and paper.

183. Paired t-test. The methodological scores are higher here than for other samples studied for this article. The higher scores are likely because methodology was measured on a per-paper or per-patent basis, rather than on a per-experiment basis as was done for the remainder of this article. This would occur if, for example, one experiment in a patent randomized but another experiment did not.

184. For one, they are more likely to be filed by an academic institution.

185. 35 U.S.C. $\S 101$ (2012).

186. Id. $\S 112(\mathrm{a})$.

187. Id. § 112(b).

188. See infra Figure 4. 
suggests that the PTO does not evaluate patents based on their potential for replicability. ${ }^{189}$

Using the same methodology as described above, I randomly selected 250 animal experiments from patent applications and scored the methodology. The mean aggregate score for patent applications is not significantly different from granted patents ( 1.38 vs. $1.44, p=0.5)$. I obtained data on rejections from the USPTO's Office Action Research Dataset. ${ }^{190}$ I obtained data on patent grant from Google Patents. Patent grant was defined as the grant of a U.S. patent that was either directly derived from the application in question or from a continuation or divisional of the application in question. ${ }^{191}$ Data on grants was collected in July 2018 and so is current up to that date. There is no significant correlation between methodological quality and likelihood of patent grant (logit regression; $\mathrm{p}=0.9$ ). ${ }^{192}$

Figure 4 shows the correlation between methodology score and likelihood that an application will be rejected for lack of enablement, written description, or utility. Because it takes several years for an application to be processed by the PTO, the first rejection may not occur for several years after the patent is filed; therefore, the regression includes an offset to control for years since filing. ${ }^{193}$ There is no significant correlation between the methodological quality of an experiment in a patent application and the likelihood that the application will be rejected on the grounds studied.

Figure 4: Correlation Between Methodology Score and PTO Rejections $(\mathrm{N}=250)$ Logistic Regression

\begin{tabular}{|c|c|c|c|c|}
\hline & $\begin{array}{c}\text { Rejected for } \\
\text { lack of } \\
\text { enablement }\end{array}$ & $\begin{array}{c}\text { Rejected for } \\
\text { lack of } \\
\text { written } \\
\text { description }\end{array}$ & $\begin{array}{c}\text { Rejected for } \\
\text { lack of utility }\end{array}$ & $\begin{array}{c}(4) \\
\text { Rejected for } \\
\text { any of lack of } \\
\text { enablement, } \\
\text { written } \\
\text { description, } \\
\text { or utility }\end{array}$ \\
\hline $\begin{array}{c}\text { Methodology } \\
\text { Score }\end{array}$ & $\begin{array}{c}0.2 \\
(\mathrm{p}=0.3)\end{array}$ & $\begin{array}{c}0.2 \\
(\mathrm{p}=0.5)\end{array}$ & $\begin{array}{c}0.1 \\
(\mathrm{p}=0.6)\end{array}$ & $\begin{array}{c}0.2 \\
(\mathrm{p}=0.4)\end{array}$ \\
\hline
\end{tabular}

189. See infra Figure 4.

190. Office Action Research Dataset, USPTO (Aug. 14, 2017), https://www.uspto.gov /learning-and-resources/electronic-data-products/office-action-research-dataset-patents [https://perma.cc/2Q2J-E8VG]. For a description of the dataset, see Qiang Lu, Amanda Myers \& Scott Beliveau, USPTO Patent Prosecution Research Data: Unlocking Office Action Traits (USPTO, Working Paper No. 10, 2017), https://papers.ssrn.com/sol3/papers.cfm?abstract_id $=3024621$ [https://perma.cc/AM8D-VN6V].

191. Google Patents, GOOGLE, https://patents.google.com.

192. Because patent grant often takes many years, the regression included an offset to control for the number of years since the patent's priority date.

193. Dennis Crouch, How Long Do I Wait for a First Office Action, PATENTLY-O (Feb. 19, 2007), https://patentlyo.com/patent/2007/02/how_long_do_i_w.html [https://perma.cc/4AHT $-\mathrm{J} 78 \mathrm{Y}]$. 


\section{Change Over Time}

There is evidence that the methodological quality of experiments in scientific papers is improving over time. ${ }^{194}$ I tested whether this also held true in patents. It does, but the magnitude of the change is small. Regressing methodology scores on priority year for patent applications shows that the methodology score is improving by 0.03 units per year $(p=0.04)$. While the directionality of the trend is encouraging, progress is slow - at this rate it would take thirty-three years to improve the mean methodology score in applications by one point.

\section{Industry and Academia}

The irreplicability debate in the scientific literature pits industry against academia. ${ }^{195}$ Academia generates most of the irreplicable articles, while industry must spend millions of dollars verifying results produced by academics. ${ }^{196}$ Because patents are filed by both academic institutions and industry, they provide a rare opportunity to compare the experimental design of academic and industry scientists. I manually classified the 250 granted patents in my sample as being filed by either industry or the academy based on the original assignee listed on the patent. ${ }^{197}$

As shown in Figure 5, there is no significant difference in methodological quality between academic and industry patents. This suggests that irreplicability is also a problem in industry. These results are interesting because pharmaceutical companies carefully verify the replicability of results before conducting clinical trials, but apparently do not before filing a patent. ${ }^{198}$ One explanation for this discrepancy is the relative cost of filing a patent and conducting a clinical trial. Filing a patent costs tens or hundreds of thousands of dollars. Conducting a clinical trial costs tens of millions of dollars (or more). ${ }^{199}$ It may be that the cost of patenting is too low to incentivize careful review of data before filing. ${ }^{200}$ This suggests that a steep increase in the cost of filing patents might increase the reliability of the data therein. ${ }^{201}$

194. See supra note 180.

195. B. R. Jasny et al., Fostering Reproducibility in Industry-Academia Research, 357 SCI. 759,759 (2017) (“[M] any industry researchers distrust quality control in academia and . . . question whether academics value reproducibility as much as rapid publication.”).

196. Id. at 760 .

197. Government patents were classified with academic patents. Patents filed by individuals were classified in a separate category.

198. Jasny et al., supra note 194 , at 760 .

199. Linda Martin, Melissa Hutchens, Conrad Hawkins \& Alaina Radnov, How Much Do Clinical Trials Cost?, 16 NAture Revs. Drug Discovery 381, 381 (2017).

200. This relates to a widespread debate about the appropriate cost of filing a patent. Many scholars have examined increasing the cost of filing or maintaining a patent as a mechanism to improve patent quality. See, e.g., Brian J. Love, An Empirical Study of Patent Litigation Timing: Could A Patent Term Reduction Decimate Trolls Without Harming Innovators? 161 U. PA. L. ReV. 1309, 1356 (2013); Jonathan S. Masur, Costly Screens and Patent Examination, 2 J. Legal AnAlysis 687, 700 (2010); David S. Olson, Removing the Troll from the Thicket: The Case for Enhancing Patent Maintenance Fees in Relation to the Size of a Patent Owner's Patent Portfolio, 68 Fla. L. REV. 519, 521 (2017).

201. Although, for reasons described in Section III.A, I do not recommend this as a policy 
Alternatively, it may be that patents have significant value to the patentee beyond the technical use of the science described in them, ${ }^{202}$ or that the pressures to file patents early in the life cycle of an invention are high enough that companies have no time to ensure replicability. ${ }^{203}$

Figure 5: Mean Methodological Score for Industry and Academic Patents $(\mathrm{N}=250)$

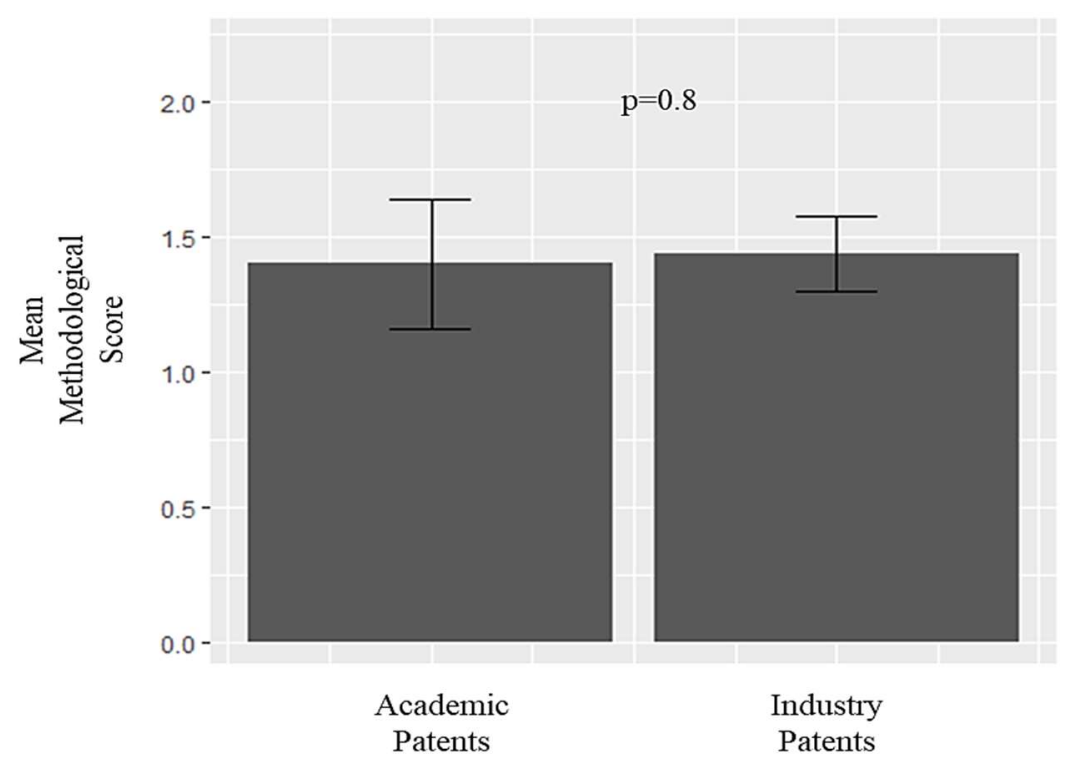

\section{Mechanism}

Why is the methodological quality of experiments in biomedical patents likely so poor? First, it suggests that patenting is about more than obtaining a patent that works - that there is also value to patentees in obtaining patents that are not functional. This fits with the literature on the value of patents as signals, as defensive mechanisms, and as part of portfolios, where the advantage of the patent lies not in the technology itself, but in the ability of the patentee to claim ownership of a granted patent. ${ }^{204}$ If patents provide benefits beyond covering functional technology, then patentees are not incentivized to carefully test technology before filing a patent. As a result, patents will have more irreplicable experiments.

For the same reasons described above with respect to the scientific literature, incentivizing companies to file greater numbers of patents could lead to poor methodology ${ }^{205}$ If the goal is to obtain a finding that looks novel and nonobvious,

change. See infra Section III.A.

202. For instance, as signals or as defensive mechanisms. See supra Section I.B.2.

203. The patent system creates substantial pressure for inventors to file patents as soon as possible. See, e.g., Cotropia, supra note 37, at 68; Sichelman, supra note 26, at 348-51.

204. See supra Section I.B.2.

205. See supra Section II.A. 
then there is less incentive to use good methodological techniques such as randomization, blinding, and statistical analysis. ${ }^{206}$ Patentees would, of course, prefer to hold patents on working technologies, and I am not suggesting that they are deliberately trying to be wrong. However, implementing better methodology takes time and attention, and will not happen if it is not specifically incentivized.

Second, the experiments in patents are early-stage experiments. The patent system is strongly oriented towards pushing inventors to file for patent protection as early as possible. ${ }^{207}$ Most notably, the patent system recently moved to a "first-to-file" regime, wherein the patent is awarded to the first inventor to file an application with the PTO. ${ }^{208}$ When two inventors are both developing similar technologies, the inventor who wins the race to the patent office gets the patent. Since an inventor cannot be sure that no others are working on the same technology, she must file her application quickly. ${ }^{209}$

This means that inventors cannot wait to conduct time-consuming experiments before filing a patent. If the inventor chooses to include an experiment in a patent, that experiment will inevitably be quick and preliminary. Preliminary experiments are, by their nature, likely to be less methodologically thorough than subsequent experiments. The purpose of a preliminary experiment is often to determine if a technology looks promising - a promise which can be confirmed through more extensive experimentation later. Preliminary experiments might therefore be done with a small number of samples (and perhaps such experiments would not specify the number of samples in order to avoid disclosing a very low number). Further, the inventor might not take the time to conduct replicates. Thus, the patent system's bias towards early-stage experiments could contribute to lower quality experiments disclosed in patents.

\section{EFFECTS OF IRREPLICABILITY}

Irreplicability rates of experiments in biomedical patents are likely comparable to those in scientific papers - meaning that perhaps up to almost $90 \%$ of these experiments are irreplicable. ${ }^{210}$ The irreplicability of experiments, however, is just the tip of the iceberg. Only $45 \%$ of biomedical patents have any experimental data at all-the remaining $55 \%$ are supported purely by speculative and hypothetical evidence. ${ }^{211}$ These speculative patents may be even less likely to be accurate than patents supported by experiments. ${ }^{212}$

206. See supra Section II.A.

207. Sichelman, supra note 26 , at 343 .

208. 35 U.S.C. $\S 102$ (2012).

209. David S. Abrams \& R. Polk Wagner, Poisoning the Next Apple? The America Invents Act and Individual Inventors, 65 STAN. L. REV. 517, 529 (2013) (suggesting that some organizations might, in the absence of a first-to-file system, prefer to wait until the technology is further developed).

210. As prior studies have found that up to $90 \%$ of preclinical experiments in scientific papers are irreplicable. Begley \& Ellis, supra note 1, at 532.

211. Freilich, supra note 9 , at 31 tbl.1 (finding that 523,710 out of $1,160,471$ biology and chemistry patents granted between 1976 and 2017 have working examples).

212. E.g., Cotropia, supra note 37, at 123 (suggesting that actual reduction to practice 
Such high irreplicability rates have serious implications for both the functioning of patent law and for the way that scholars understand patent theory. Section III.A, below, discusses implications for patent law. Section III.B turns to patent theory and scholarship. Section III.C proposes policy reform.

\section{A. Implications for Patent Law}

What is the effect of having irreplicable experiments in patents? One might assume that if an experiment does not work, then the patent will be harmless-since it covers nonfunctional technology - and therefore, there is no cost to the public in giving away the exclusive right, since the right does not cover anything useful. However, there are indeed harms to the public from irreplicable experiments in patents, and I set them out here.

\section{Waste and Inefficiency}

In the context of the scientific literature, much irreplicability arises from poor experimental design and could be avoided by taking proper precautions. ${ }^{213}$ These experiments waste resources. It is expensive to purchase labor and materials to conduct experiments, and this is wasted if those experiments do not produce useful results. Such experiments are equally wasteful in the patent context. Further, there is a cost to drafting and filing a patent. ${ }^{214}$ Assuming that a patent covering a technology that does not work creates little or no social value, the cost of drafting and filing that patent - between $\$ 10,000$ and $\$ 20,000$ per patent ${ }^{215}$ —is wasted. ${ }^{216}$

\section{Inoperable Patents}

A major consequence of irreplicable experiments in patents is that many patents will disclose technologies that do not work. Patent doctrine terms such patents

allows the inventor to "gain[] a better handle on whether the invention provides the wanted results").

213. E.g., Iain Chalmers \& Paul Glasziou, Avoidable Waste in the Production and Reporting of Research Evidence, 374 LANCET 86, 86 (2009); see also Douglas G. Altman, The Scandal of Poor Medical Research, 308 BRITISH MED. J. 283, 283 (1994) ("Huge sums of money are spent annually on research that is seriously flawed through the use of inappropriate designs, unrepresentative samples, small samples, incorrect methodology, and faulty interpretation.").

214. Lemley, supra note 38, at 1498; Gene Quinn, The Cost of Obtaining a Patent in the US, IP WATCHDOG (Apr. 4, 2015), http://www.ipwatchdog.com/2015/04/04/the-cost-ofobtaining-a-patent-in-the-us/id=56485/ [https://perma.cc/A8LX-U42M].

215. Lemley, supra note 38, at 1498-99.

216. Patents on technologies that do not work likely still create private value for the firm that files them. Patents have value as signals of technological accomplishment (whether or not they actually work) and often sheer volume of patents is a source of value for companies. See, e.g., Clarisa Long, Patent Signals, 69 U. CHI. L. ReV. 625, 626 (2002); Gideon Parchomovsky \& R. Polk Wagner, Patent Portfolios, 154 U. PA. L. ReV. 1, 6 (2005). 
"inoperable."217 There is a large literature on inoperable patents. ${ }^{218}$ The literature generally assumes that inoperable patents are widespread because patents are filed early in the invention life cycle - while they are still conceptual and before they have been physically tested. ${ }^{219}$ While this is undoubtedly one source of inoperable patents, in this Article, I emphasize that even inventions that have been physically tested can be inoperable. However, many of the problems with inoperable patents as described in the literature on early-stage patents also apply to the irreplicable patents discussed here.

To understand why inoperable patents can be harmful, one must understand two basic principles of patent law: (1) that patents obtained on the strength of an irreplicable - and therefore inoperable - experiment can still cover technology that does work; and (2) that these inoperable patents may still be valid. ${ }^{220}$ Below, I briefly explain each of these principles. I then turn to the harm caused by inoperable patents.

\section{a. Inoperable Patents Can Cover Operable Technology}

Though experiments help satisfy the requirements for patentability and are therefore instrumental evidence in obtaining a patent, patents can be far broader than just the material described in the experiment. ${ }^{221}$ The experiment demonstrates one way in which the invention can be used, but through this experiment an inventor can get a patent covering all ways in which an invention can be used. ${ }^{222}$ To illustrate, the patent on sildenafil (Viagra ${ }^{\circledR}$ ) describes experiments showing the drug's efficacy at

217. E.g. Brooktree Corp. v. Advanced Micro Devices, Inc., 977 F.2d 1555, 1571 (Fed. Cir. 1992).

218. See, e.g., Lemley, supra note 37, at 1277 (arguing that the patent system privileges untested ideas over inventions that are physically reduced to practice); Michael Risch, Reinventing Usefulness, 2010 BYU L. REV. 1195, 1198 (discussing the dimensions of operability); Daniel C. Rislove, A Case Study of Inoperable Inventions: Why is the USPTO Patenting Pseudoscience? 2006 WIS. L. REV. 1275, 1313 (arguing that patents that rest on "clearly pseudoscientific principles" should not be granted); Sean B. Seymore, Making Patents Useful, 98 MinN. L. REv. 1046, 1092 (2014) (suggesting that the utility doctrine is not necessary to prevent inoperable patents because they can be excluded by the enablement requirement).

219. See, e.g., Cotropia, supra note 37, at 65 (2014); Lemley, supra note 37, at 1198; Ouellette, supra note 37, at 1830; Sichelman, supra note 26, at 343.

220. See infra Section III.A.2.b.

221. E.g., Cont'l Paper Bag Co. v. E. Paper Bag Co., 210 U.S. 405, 418-19 (1908) (explaining that patents cover not only the embodiment created by the inventor, but also the "principle" of the invention); see also Janet Freilich, The Uninformed Topography of Patent Scope, 19 STAN. L. REV. 150, 152 (2015).

222. This is because the utility requirement is satisfied by disclosure of one way in which the invention is useful, and the enablement requirement is satisfied by disclosure of one way in which the invention can be made or used. Thus, one experiment can enable a far broader claim. See, e.g., MPEP, supra note $55 \S 2164.01$ (b) (“As long as the specification discloses at least one method for making and using the claimed invention that bears a reasonable correlation to the entire scope of the claim, then the enablement requirement of 35 U.S.C. 112 is satisfied."); see also CFMT, Inc. v. Yieldup Int'l. Corp., 349 F.3d 1333, 1338-39 (Fed. Cir. 2003); Johns Hopkins Univ. v. CellPro, Inc., 152 F.3d 1342, 1359-61 (Fed. Cir. 1998). 
treating hypertension. ${ }^{223}$ These experiments were sufficient to support the validity of a claim to sildenafil generally-i.e. the patent covered any use of sildenafil. ${ }^{224}$ This broad claim became a goldmine when doctors realized that sildenafil's most profitable use was not the treatment of hypertension but the treatment of erectile dysfunction. ${ }^{225}$

\section{b. Inoperable Patents Can Still Be Valid}

If an experiment in a patent does not work, is the patent invalid? The answer depends on the other content of the patent. First, the requirements of patentability apply to the patent claim as a whole, rather than to individual experiments. ${ }^{226}$ Thus, if an experiment teaching how to make some aspect of the claimed invention is irreplicable but a scientist could still figure out how to make the invention as a whole without undue experimentation, the claim is enabled. ${ }^{227}$ It is well established in case law that a patent that claims some totally inoperative variations on the invention can still be enabled. ${ }^{228}$ Thus, merely because one experiment in a patent is irreplicable, it does not mean that the claimed invention as a whole will be deemed nonenabled. ${ }^{229}$ Similarly, if a claim is enabled by just one embodiment in the specification and that embodiment is inoperable, the claim is invalid, but if the specification contains multiple possible embodiments, then one inoperative embodiment will not render the

223. U.S. Patent No. 5,250,534 col. 6, 11. 35-59 (filed May 14, 1992). Note that the experiments in question are prophetic.

224. Id. at claim 1.

225. See Pfizer, How Does Viagra Work?, VIAGRA, https://www.viagra.com/learning/howdoes-viagra-work [https://perma.cc/7MDH-N9XC].

226. For example, the MPEP instructs patent examiners to assess whether the inventor has enabled the invention that is "defined by the claim(s) of the particular application or patent." MPEP, supra note 55, § 2164.

227. See Application of Cook, 439 F.2d 730, 735 (1971) (“[M]any patented claims read on vast numbers of inoperative embodiments .... There is nothing wrong with this so long as it would be obvious to one of ordinary skill in the relevant art how to include those factors [that are omitted in the description of the embodiments] in such manner as to make the embodiment operative rather than inoperative."). There is no clear line as to what precisely constitutes undue experimentation and it varies with context, but case law suggests that quite a bit of experimentation can be permitted. For example, in one case the Federal Circuit held that three years of experimentation was not undue. See Transocean Offshore Deepwater Drilling, Inc. v. Maersk Drilling USA, Inc., 699 F.3d 1340, 1356 (Fed. Cir. 2012). However, in another case the Federal Circuit found that experimentation of eighteen months to two years was undue. See Cephalon, Inc. v. Watson Pharm., Inc., 707 F.3d 1330, 1336 (Fed. Cir. 2013). For further discussion of the link between reproducibility and enablement, see Dmitry Karshtedt, Limits on Hard-to-Reproduce Inventions: Process Elements and Biotechnology's Compliance with the Enablement Requirement, 3 Hastings SCI. \& TeCH. L.J. 109, 111-12 (2011).

228. Atlas Powder Co. v. E.I. Du Pont de Nemours \& Co., 750 F.2d 1569, 1576 (Fed. Cir. 1984) ("Even if some of the claimed combinations were inoperative, the claims are not necessarily invalid."); see also Application of Myers, 410 F.2d 420, 426 (C.C.P.A. 1969); Warner Lambert Co. v. Teva Pharm. USA, Inc., No. 99-922(DRD), 2007 WL 4233015, at*12 (D.N.J. Nov. 29, 2007).

229. However, if many or most embodiments of the claim are inoperative, the claim may be invalid. See Graver Tank \& Mfg. Co. v. Linde Air Products Co., 336 U.S. 271, 276 (1949). 
claim invalid, as long as the other embodiment is enabled. ${ }^{230}$ For example, if a patent discloses two cell lines that can be used to produce the claimed antibodies, but the antibodies can only be produced from one of those cell lines, then the patent is still valid. $^{231}$

\section{c. Harm from Inoperable Patents}

Because irreplicable experiments can be used to obtain valid patents that cover functional technology, there is the potential for several types of harm. First, owners of inoperable patents may still seek rents from other inventors. Suppose I discover a molecule that I believe cures cancer. I test this molecule in mice, and find that I am correct, so I apply for and obtain a patent covering the molecule. Patents of this type typically give the patentee the exclusive right to the molecule for any use at all, so my patent claim is not restricted to using the molecule to treat cancer, but rather covers all possible applications. ${ }^{232}$

It turns out that my experiments on mice are not replicable, and in fact the molecule does nothing whatsoever to treat cancer. However, another inventor, unaware of my findings, discovers that the compound treats HIV. Her results are replicable, and the compound becomes a blockbuster drug. Although I was wrong, she was right, and she did not rely on any information from my patent, ${ }^{233}$ she owes me royalties unless she can prove that my patent is invalid - an expensive and uncertain proposition, since granted patents enjoy a presumption of validity. ${ }^{234}$ Thus, patents built on irreplicable experiments can drain funds from inventors who did better.

Inoperable patents may also prevent downstream patenting. As in the scenario above, I have patented my newly discovered molecule. After a period of time, my patent expires and I can no longer seek damages from others who use the molecule. ${ }^{235}$ Another inventor, again unaware of my findings, discovers that the molecule can in

230. E.g., Johns Hopkins Univ. v. CellPro, Inc., 152 F.3d 1342, 1361 (Fed. Cir. 1998).

231. Id. (finding that patent was valid even though defendant alleged that "no one ever succeeded in making CD34 antibodies using ... purified My-10+ cells" because the defendant did not allege that antibodies could not be made using the KG-1/KG-1 a cell lines, which were also disclosed in the patent).

232. See supra Section III.A.1.2.a; see also Amy Kapczynski, Chan Park \& Bhaven Sampat, Polymorphs and Prodrugs and Salts (Oh My!): An Empirical Analysis of "Secondary" Pharmaceutical Patents, PLOS ONE, Dec. 2012, at 1-3.

233. This is because there is no independent invention defense in U.S. patent law. See Mark A. Lemley, Should Patent Infringement Require Proof of Copying?, 105 MicH. L. REV. 1525 , 1526 (2007); Samson Vermont, Independent Invention as a Defense to Patent Infringement, 105 Mich. L. REV. 475, 476 (2006). More drastic than royalties, I could obtain an injunction and start selling her product myself. This may be harder after eBay Inc. v. Mercexchange, L.L.C., 547 U.S. 388, 394 (2006), which made injunctions more difficult to obtain, particularly for nonpracticing entities.

234. See Impax Labs., Inc. v. Aventis Pharm. Inc., 468 F.3d 1366, 1383 (Fed. Cir. 2006).

235. Patents generally expire twenty years after filing; however, many patents expire earlier for failure to pay maintenance fees to the Patent Office, and this might be particularly likely to occur in a patent covering a technology that does not work. Freilich, supra note 9, at 36. 
fact cure cancer, only at much higher doses than I used. This inventor tries to pitch his discovery to pharmaceutical companies only to find that nobody is interested because he cannot obtain a patent on his discovery. Patents are only granted on new and nonobvious inventions, and I had previously disclosed that the molecule could cure cancer. ${ }^{236}$ Thus, this inventor cannot get a patent on use of the molecule to cure cancer. ${ }^{237}$ In this way, irreplicable results can disincentivize later research.

\section{Impeding the Goals of the Patent System}

Irreplicable experiments do not achieve the foundational goals of the patent system. Patents with irreplicable experiments give their owners an exclusive right, but the public does not get their part of the bargain in return. These patents disclose technologies that do not work, so there is no useful innovation obtained by society. Further, the patents do not communicate useful information, since the experiments are wrong. Just as the replicability crisis has diminished the public trust in science, so too can disclosure of irreplicable information in patents diminish public trust in patents. In theory, patents are supposed to be a public repository of technical information that scientists can access to obtain the details of cutting-edge innovations. ${ }^{238}$ In practice, scientists already distrust the information provided in patents and think it low quality, ${ }^{239}$ although scientists do read patents. ${ }^{240}$ If most experiments in patents are wrong, scientists may stop reading patents altogether.

The public also loses the potential to leverage the patent system to incentivize the disclosure of useful information in the future. If company A is granted a patent on the basis of an irreplicable experiment, but later figures out how to make the experiment work, company A can keep those details secret, since they already have a patent. If company $\mathrm{B}$ is the one to discover how to make the invention work, company $\mathrm{B}$ is also not incentivized to disclose because they may not be able to get their own patent.

\section{Experimentation Stops}

Some scientists downplay the replicability crisis, saying that irreplicability is just part of the scientific process. ${ }^{241}$ In this view, the scientific process naturally addresses

236. There are some complexities here, because a previous disclosure will only anticipate a patent if it is enabled, which my invention may not have been (though it also may have been-irreplicability does not mean nonenablement). MPEP, supra note 55, 2121 . However, a nonenabled disclosure can still render a later patent obvious. Symbol Techs., Inc. v. Opticon, Inc., 935 F.2d 1569, 1578 (Fed. Cir. 1991); MPEP, supra note 55, § 2121.01. And even if the invention is patentable, it may be sufficiently at risk of later invalidation that companies will not invest. See Benjamin N. Roin, Unpatentable Drugs and the Standards of Patentability, 87 TEX. L. REV. 503, 536 (2008).

237. He might be able to get a patent on use of the higher dose, but these patents are not as strong. See Roin, supra note 235, at 548.

238. See Ouellette, supra note 16, at 571.

239. Id.

240. Ouellette, supra note 22, at 422.

241. See, e.g., A. David Redish, Erich Kummerfeld, Rebecca Lea Morris \& Alan C. Love, 
irreplicability by encouraging constant testing and development of previous findings. The problem with irreplicability in the context of patents is that once an inventor obtains a patent on their findings, this sort of iterative experimentation stops. Other scientists cannot test or verify the patented findings because doing so would be patent infringement.

There is a defense to infringement-the experimental-use exception - that may deal with precisely this scenario. The defense was first applied by Justice Story, who explained that it could not be infringement if the defendant had used the invention "for mere purpose of philosophical experiment, or to ascertain the verity and exactness of the specification." 242 For the next two centuries, the experimental-use exception would probably have covered a situation where a scientist attempted to replicate an experiment in a patent in order to determine if the experiment worked. ${ }^{243}$ However, in 2002 the Federal Circuit decided Madey v. Duke University, which significantly narrowed the experimental-use exception. ${ }^{244}$ Research for business purposes is excluded from the experimental-use exception, and the court in Madey held that research by university faculty is for a business purpose, since universities are in the business of research. ${ }^{245}$ Madey was widely perceived as destroying the experimental-use exception. ${ }^{246}$

In a post-Madey world, it is not clear whether or not attempting to replicate an experiment in a patent would constitute patent infringement. ${ }^{247}$ There have been various proposals to institute an exception that would allow replication. These proposals suggest that scholars are skeptical that the post-Madey experimental-use exception would currently include replication. ${ }^{248}$ This uncertainty can chill scientists' willingness to test experiments in patents for replicability. Patent law therefore cuts

Reproducibility Failures Are Essential to Scientific Inquiry, 115 PROC. NAT'L ACAD. SCI. 5042, 5045 (2018) ("Many of the current concerns about reproducibility overlook the dynamic, iterative nature of the process of discovery where discordant results are essential to producing more integrated accounts and (eventually) translation. A failure to reproduce is only the first step in scientific inquiry."); Art Markman, Why Science Is Self-Correcting, PSYCHOL. TODAY (Aug. 10, 2010), https://www.psychologytoday.com/us/blog/ulterior-motives/201008 /why-science-is-self-correcting [https://perma.cc/3HB9-P8L8].

242. Sawin v. Guild, 21 F. Cas. 554, 555 (Story, Circuit Justice, C.C.D. Mass. 1813).

243. See, e.g., Rebecca S. Eisenberg, Patents and the Progress of Science: Exclusive Rights and Experimental Use, 56 U. CHI. L. REV. 1017, 1075 (1989) (arguing that Justice Story's analysis "suggests a function for the experimental use doctrine in the patent system that is analogous to that of replication of scientific experiments . . . [To] provide a check against fraud or error in research claims by subjecting research results to potential replication ....").

244. See 307 F.3d 1351, 1354 (Fed. Cir. 2002), cert. denied, 123 S. Ct. 2639 (2003).

245. See id.

246. E.g., Michelle Cai, Madey v. Duke University: Shattering the Myth of Universities' Experimental Use Defense, 19 BERKELEY TECH. L.J. 174, 190 (2004).

247. Experiments directed specifically towards generating information for FDA approval fall within a statutory experimental use exception. 35 U.S.C. $§ 271(\mathrm{e})(1)(2012)$; see also Momenta Pharm., Inc. v. Teva Pharm. USA Inc., 809 F.3d 610, 615 (Fed. Cir. 2015).

248. See Tom Saunders, Rending Space on the Shoulders of Giants: Madey and the Future of the Experimental Use Doctrine, 113 Yale L.J. 261, 261 (2003); Cristina Weschler, The Informal Experimental Use Exception: University Research After Madey v. Duke University, 79 N.Y.U. L. REV. 1536, 1547-48 (2004). 
off one mechanism to improve replicability. Further, this patent doctrine might be making the irreplicability crisis worse not just for patents but also for scientific articles. Because many scientists file patents on the same invention described in scientific articles, patents preclude not only testing of experiments in patents but also testing of experiments in scientific articles.

\section{B. Implications for Patent Theory and Scholarship}

Irreplicability creates structural challenges for patent law. Most of the classic theories of patent law rest on the assumption that patents work. If patents are a reward for inventing (reward theory), then we presumably want to reward only inventions that work. ${ }^{249}$ If patents are an incentive to create inventions that would not otherwise be developed in the absence of the grant of exclusivity (patent-induced theory), then we should primarily seek to incentivize inventions that work. If patents are a prospect through which the patentee can coordinate downstream development (prospect theory), then the patentee must be capable of creating a version that works. ${ }^{250}$

Further, as explored above, the utility, enablement, and written description doctrines all require that the invention works. ${ }^{251}$ If not, patents will be granted on useless inventions, given to the wrong inventor, and will not teach others how to make and use the invention. If inventions are irreplicable, then patents on those inventions do not accomplish the basic goals of the patent system: to promote the progress of science through the creation and disclosure of useful, working technology. ${ }^{252}$

Although this Article focuses on irreplicable experiments, these experiments do not necessarily reflect bad science. Certainly, many of the experiments could be better designed, but as explained above, many of these experiments are simply early stage and preliminary. It is the nature of the preliminary experiments to be speculative and often wrong. We would not want to dissuade this-experimenters should be encouraged to try ideas that might not work. To this end, it is good if preliminary experiments are done in ways that are cheap and easy-for instance, using a small sample size — even if that reduces the likelihood that the results will be replicable.

The problem is not, therefore, that some experiments in patents are irreplicable. The problem is that the patent system is structured to put unmerited weight on the results of such experiments. We give a powerful legal right - the right to exclude others from making and using the invention ${ }^{253}$ - to patentees on the basis of these initial experiments. Though preliminary experimental results are inherently tentative, the patent system uses them as a basis for attaching rights with force and permanence. Experiments are very likely to be wrong; but patent rights are very hard to undo.

249. A. Samuel Oddi, Un-Unified Economic Theories of Patents-The Not-Quite-Holy Grail, 71 Notre Dame L. ReV. 267, 275 (1996).

250. Edmund W. Kitch, The Nature and Function of the Patent System, 20 J.L. \& ECON. 265, 269 (1977) ("The patent application need not disclose a device or process of any commercial value, only a version of the invention that will work.").

251. See supra Section I.B.1.

252. Id.

253. 35 U.S.C. $§ 271$ (2012). 
With this new understanding - that patents are based on early-stage, and therefore often irreplicable, experiments - there are several major ways in which we should revise patent theory.

\section{Probabilistic Functionality}

First, instead of assuming that patents work, we should think of these patents as probabilistic - a roll of the dice. ${ }^{254}$ This has been discussed in the context of value to the patentee, ${ }^{255}$ but it also applies to value to society: when we grant a patent, there is a significant chance that it will not represent a useful innovation. Nonetheless, the possibility that the patent will represent a useful innovation may be big enough that we should keep granting patents. ${ }^{256}$

The import of this shift for patent policy and scholarship is that we must focus more attention and energy on the possibility that patents are not functional. There is an enormous volume of scholarship and policy work on "bad patents"- that is, patents that were erroneously granted. Patents can be erroneously granted for many reasons; if they are granted by the PTO but in fact fail to satisfy any of the requirements of patentability. ${ }^{257}$ However, the overwhelming bulk of this scholarship and policy work has focused on patents that fail to satisfy the novelty and nonobviousness requirements. ${ }^{258}$ These are patents that disclose technologies that

254. Mark A. Lemley \& Carl Shapiro, Probabilistic Patents, 19 J. ECON. PersP. 75, 75 (2005).

255. Id.

256. Whether the patent system actually accomplishes the goal of increased innovation is an empirical question that is hard to definitively answer.

257. 35 U.S.C. $\S 101$ (2012) (permitting patents on new and useful inventions as long as the inventions meet the "conditions and requirements of this title").

258. See Lemley, supra note 38, at 1496 n.3 (2001) (calling the complaints "legion" and suggesting that the problem arises because the PTO cannot properly search the prior art to determine if the patent is novel and nonobvious); see also John R. Allison \& Mark A. Lemley, Empirical Evidence on the Validity of Litigated Patents, 26 AIPLA Q.J. 185, 208 (1998); Robert D. Atkinson \& Daniel D. Castro, A National Technology Agenda for the New Administration, 11 YALE J.L. \& TECH. 190, 193 (2009); Joseph Farrell \& Robert P. Merges, Incentives to Challenge and Defend Patents: Why Litigation Won't Reliably Fix Patent Office Errors and Why Administrative Patent Review Might Help, 19 BERKELEY TeCH. L.J. 943, 94446 (2004); Roger Allan Ford, Patent Invalidity Versus Noninfringement, 99 CORNELL L. REV. 71, 73 (2013); Michael D. Frakes \& Melissa F. Wasserman, Does Agency Funding Affect Decisionmaking: An Empirical Assessment of the PTO's Granting Patterns, 66 Vand. L. Rev. 67, 71 (2013); Mark A. Lemley, Ignoring Patents, 2008 Мich. ST. L. REV. 19, 20; Mark A. Lemley \& Bhaven Sampat, Is the Patent Office a Rubber Stamp? 58 EMORY L.J. 181, 185 (2008); Lichtman \& Lemley, supra note 34, at 47; Robert P. Merges, As Many as Six Impossible Patents Before Breakfast: Property Rights for Business Concepts and Patent System Reform, 14 BeRKeley TECH. L.J. 577, 589 (1999); Michael J. Meurer, Controlling Opportunistic and Anti-Competitive Intellectual Property Litigation, 44 B.C. L. REV. 509, 541 (2003); Arti K. Rai, Growing Pains in the Administrative State: The Patent Office's Troubled Quest for Managerial Control, 157 U. PA. L. REv. 2051, 2080 (2009); David Schumann, Obviousness with Business Methods, 56 U. Miami L. ReV. 727, 764 (2002); R. Polk Wagner, Understanding Patent-Quality Mechanisms, 157 U. PA. L. Rev. 2135, 2139 (2009). See generally James Bessen \& Michael Meurer, Patent Failure: How Judges, Bureaucrats, 
either have been disclosed before or are obvious variations of previous inventions. ${ }^{259}$ As such, the disclosed invention is already available to society, and so the patent does not provide society with any benefit. This problem has been so well characterized and advocated for that it led to a major policy change: the availability of inter partes review, beginning in 2012. ${ }^{260}$ Inter partes review allows third parties to challenge the validity of a patent before a PTO tribunal, at a substantial cost and time savings compared to going through the court system. ${ }^{261}$ The catch is that inter partes review is only available for those challenging patents on novelty or nonobviousness grounds - it cannot be used to challenge patents on the basis that the patent does not work (utility and enablement). ${ }^{262}$

Policy and scholarship on "bad patents" has focused predominantly on novelty and nonobviousness - not on utility and enablement. There are a small number of scholars who have consistently written about problems with utility and enablement, ${ }^{263}$ but the bulk of the attention has gone to novelty and nonobviousness. Further, policy changes have been focused on easing invalidation of anticipated or obvious patents rather than on patents that do not work. ${ }^{264}$ The existing scholarly and policy efforts are certainly worthwhile, but the findings of this Article suggest that a substantial number of patents are "bad patents" because they do not work-and therefore that scholars and policy makers should devote more efforts in that direction.

\section{Functionality as a Spectrum}

Although the majority of "bad patent" scholarship has focused on problems with novelty and nonobviousness, some scholarship does concern the possibility that inventions do not work. The findings of this Article necessitate a shift in our thinking about this scholarship - in particular, the question of what it means for an invention to work. There is a mismatch between patent law's conception of operability and how that concept has been developed in the scientific literature on replicability. Patent law assumes that there is a point in time after which an invention has been "reduced to practice" - meaning that the invention works. ${ }^{265}$ In fact, the functionality

and Lawyers Put Innovators at Risk (2008); Dan Burk \& Mark Lemley, The Patent CRISIS AND How the COURTS CAN SOLVE IT (2009); ADAM JAFFE \& JOSH LERNER, INNOVATION AND ITS DISCONTENTS (2004).

259. 35 U.S.C. $\S \S 102,103$ (2012).

260. 35 U.S.C. $\S 311$.

261. J. Steven Baughman, Choosing Inter Partes Reexamination or Review: What to File, and When?, 24 Intell. Prop. \& TeCh. L.J. 8, 8 (2012).

262. Inter Partes Review, USPTO (May 19, 2017), https://www.uspto.gov/patents -application-process/appealing-patent-decisions/trials/inter-partes-review [https://perma.cc /YS76-M4Z6].

263. See supra note 37.

264. Most notably, inter partes review, which allows third parties to challenge the validity of a patent before a PTO tribunal, but can only be used to challenge patents for anticipation or obviousness. See supra note 261.

265. See, e.g., Estee Lauder Inc. v. L'Oreal, S.A., 129 F.3d 588, 593 (Fed. Cir. 1997); King Instrument Corp. v. Otari Corp., 767 F.2d 853, 860 (Fed. Cir. 1985); Wetmore v. Quick, 536 F.2d 937, 942 (C.C.P.A. 1976). Note that these cases are in the context of interference proceedings, which do not apply to patents filed after the America Invents Act. However, the 
of the invention is not something that can be ascertained at a set point. Rather, it is a spectrum - as an increasing number of experiments are performed, we can be increasingly sure that an invention works. However, in the context of biomedical inventions - the unpredictable arts - there is sometimes no point in time when we are absolutely certain that an invention works, no matter how extensive the testing. ${ }^{266}$

Thinking about reduction to practice as a spectrum, rather than a definite point, has implications for patent scholarship. The literature divides the concept of reduction to practice into two distinct types: constructive reduction to practice and actual reduction to practice. Constructive reduction to practice occurs when the invention has been fully conceptualized, even if it has not been physically created. ${ }^{267}$ Actual reduction to practice occurs when the inventor has physically made a working invention. ${ }^{268}$ As a matter of patent law, either form of reduction to practice is sufficient for patentability. ${ }^{269}$ Scholars, however, often distinguish between the two forms of reduction to practice - generally when voicing concerns that the practice of allowing inventions to be patented when they have only been constructively reduced to practice, and not physically made, leads to patents that do not work. ${ }^{270}$

In light of this Article's findings, perhaps we should not draw such a bright-line distinction between constructive and actual reduction to practice. To be sure, allowing patents on inventions that have never actually been made likely leads to patents on technology that does not—and perhaps cannot—work. ${ }^{271}$ But, as I show here, the same is true for patents on inventions that have been physically created and tested. Crossing the line between constructive and actual reduction to practice probably does increase the likelihood that a patented invention will work. However, it may not be the main predictor of whether a patented invention will work. More relevant to the core question of operability of inventions is the extent to which the invention has been tested, the quality of those tests, and the comprehensiveness of the analysis. ${ }^{272}$

Further, it is not clear where the line between constructive and actual reduction to practice is actually located. It is generally considered crossed when some physical version of the invention has been made. ${ }^{273}$ But has there truly been actual reduction

concept of reduction to practice is more broadly applicable and remains relevant for many other aspects of current patent law.

266. See Sherkow, supra note 8 , at 886 (giving several examples of drugs that were approved by the FDA after extensive experimentation but were still later found not to work).

267. Hybritech Inc. v. Monoclonal Antibodies, Inc., 802 F.2d 1367, 1376 (Fed. Cir. 1986).

268. Id.

269. E.g., Cooper v. Goldfarb, 154 F.3d 1321, 1327 (Fed. Cir. 1998) ("A reduction to practice can be either a constructive reduction to practice, which occurs when a patent application is filed, or an actual reduction to practice.").

270. See, e.g., Cotropia, supra note 37, at 64; Freilich, supra note 9, at 5; Lemley, supra note 37, at 1171; Ouellette, supra note 37, at 1830; Seymore, supra note 37, at 145; Sichelman, supra note 26 , at 343 .

271. Freilich, supra note 9 , at 40 .

272. Patent law does not ignore these questions entirely-when determining whether testing in vitro is likely to predict utility in vivo, the Manual of Patent Examining Procedure instructs examiners to look at the quality of the experiments and the likely correlation between the experiment and claimed applications. MPEP, supra note 55, § 2164.

273. Freilich, supra note 9 , at 22. 
to practice if the inventor has tested a drug in vitro-with cells in a test tube- but not in animals? In mice, but not in humans? In healthy humans - as in a phase I clinical trial-but not in sick humans? Actual reduction to practice occurs when the invention is made, but it is far from clear what it means to make the invention. The line between constructive and actual reduction to practice is blurry.

Moreover, I am skeptical that the goal of ensuring that patented inventions "work" is achievable as an absolute matter. In some fields - life sciences in particular-it is perhaps impossible to definitively know if some inventions work. ${ }^{274}$ This is why the FDA recalls approved drugs - though the drugs have gone through decades of extensive testing, when they are used on a population-wide basis it sometimes becomes clear that they do not function as expected. ${ }^{275}$ While it is worthwhile for scholars to seek paths to improve the likely functionality of patented inventions, scholars should not talk in absolutes and should recognize that functionality is a goal that we can approach but may not be confident of arriving at.

Perhaps scholars focus on the absolute goal of making the invention work because patent law reflects that goal. Patent law, as mentioned above, assumes that patented inventions work. ${ }^{276}$ Courts give such inventions a presumption of validity, meaning a presumption that they are enabled and are useful for their stated purpose. As an extension of my argument that complete functionality is not an achievable goal, I argue that we should move away from the presumption of functionality in patent doctrine. Below, I suggest certain changes to patent doctrine that relax the presumption of functionality and better align patent doctrine with my proposal to think of functionality as probabilistic, rather than absolute.

\section{Patent Law Cannot Solve Irreplicability}

As explored above, there is a fundamental mismatch between how patent theory and doctrine treats patents (as reflecting fully formulated inventions) and what they actually are, which is early stage inventions. ${ }^{277}$ In broad terms, there are two potential solutions to this problem. First, we could heighten the evidentiary requirements for patents to a point where most patents would cover inventions that work. Second, we could accept that most patented inventions do not work and adapt the patent system to better reflect that reality. For reasons described below, I advocate for the second option.

Improving replicability is appealing in theory, but in practice the cost would be too high to justify. Measures such as randomization are cheap, but the replicability literature also recommends increased sample size, independent replicates, and testing under different conditions. ${ }^{278}$ Requiring such measures would raise the cost of

274. See Sherkow, supra note 8 , at 886 .

275. See id.

276. See supra Section I.B.

277. See supra Sections III.B.1, III.B.2.

278. E.g., Prasad Patil, Roger D. Peng \& Jeffrey T. Leek, What Should Researchers Expect When They Replicate Studies? A Statistical View of Replicability in Psychological Science, 11 PersP. Psychol. Sci. 539, 539 (2016); Benjamin O. Turner, Erick J. Paul, Michael B. Miller \& Aron K. Barbey, Small Sample Sizes Reduce the Replicability of Task-Based fMRI Studies, 1 Comm. Bio., June 2018, at 2. 
patenting, which might make the system inaccessible to some inventors. It would funnel inventors away from patenting and towards trade secrecy. ${ }^{279}$ Although deterring patenting of irreplicable inventions may be no great loss, it is likely that inventors of replicable inventions would also be deterred. ${ }^{280}$ Further, increasing disclosure requirements for experiments in patents might simply lead inventors to file patents without experiments, which is acceptable to the PTO. ${ }^{281}$

Additionally, the PTO does not have the institutional expertise to require replicability. ${ }^{282}$ Few patent examiners have $\mathrm{PhDs},{ }^{283}$ and even those that do would not necessarily know how to evaluate whether an experiment was likely to be replicable - particularly since the quantum of evidence necessary to make replicability probable would vary based on the nature of the experiment. Some have proposed peer review of patent applications, ${ }^{284}$ and bringing in peer reviewers would increase the level of expertise at the PTO. However, peer reviewers are clearly unable or unwilling to assess replicability in scientific journals, so there is no reason to think that they would function better at the PTO.

Finally, it would be prohibitively expensive for the PTO to evaluate replicability of an invention. Even if the PTO could develop the institutional expertise, sometimes verifying replicability comes down to checking whether an experiment works in the lab - something the PTO does not have the facilities to do. ${ }^{285}$ Further, the PTO would have to pay examiners more to spend more time on each patent in order to thoroughly assess replicability. This cost in increased examination fees may not be worth the benefit in more replicable patents.

In other contexts, scholars have argued that increasing the quality of PTO examination is unlikely to be worth the cost. In an essay addressing the prevalence of bad software patents, Professor Mark Lemley pointed out that since the vast majority of patents are never licensed, enforced, or litigated, many of these PTO errors have little cost. ${ }^{286}$ The expense of paying for more examiner hours to reduce

279. For a discussion of problems surrounding trade secrecy in certain areas of drug development, see W. Nicholson Price II, Expired Patents, Trade Secrets, and Stymied Competition, 92 Notre Dame L. Rev. 1611, 1620 (2017); W. Nicholson Price II, Making Do in Making Drugs: Innovation Policy and Pharmaceutical Manufacturing, 55 B.C. L. REV. 491, 495 (2014).

280. An inventor deciding whether or not to go to the expense of conducting the experiments necessary to file a patent would not know beforehand whether or not the experiment would be replicable, so replicable experiments might also be lost to trade secrecy.

281. Freilich, supra note 9, at 3.

282. See Jacob S. Sherkow, And How: Mayo v. Prometheus and the Method of Invention, 122 YALE L.J. OnLINE 351, 356-57 (2013).

283. Ouellette, supra note 123 , at 1828.

284. Id. at 1848; see also Beth Simone Noveck, "Peer to Patent": Collective Intelligence, Open Review, and Patent Reform, 20 HARV. J. L. \& TECH. 123, 143-51 (2006).

285. This already limits the ability of the PTO to examine applications. See, e.g., Ex parte Reguri \& Sunkari, No. 2007-0313, 2007 WL 2745815, at*7 (B.P.A.I. Sept. 6, 2007) ("[T] Office does not have the facilities to determine what form or admixtures of forms Buhlmayer's crystalline compound takes.”); Ex parte Baker, No. 2006-2892, 2007 WL 630236, at *3 (B.P.A.I. Feb. 26, 2007) ("[S]ince the Office does not have the facilities for examining and comparing Appellant's protein/antibody with the protein/antibody of the prior art ....").

286. See Lemley, supra note 38, at 1495-97. But see Michael D. Frakes \& Melissa F. 
the number of erroneously granted patents could exceed the cost of those bad patents. ${ }^{287}$ Lemley, therefore, recommends improving mechanisms to deal with these patents ex post (in litigation), rather than ex ante (in examination). ${ }^{288}$

I take a similar approach here. It would be too expensive for the PTO to ensure replicability ex ante, at the examination stage. However, we can create much better mechanisms for dealing with irreplicability ex post, after patent grant, in order to mitigate the harms of irreplicable experiments in patents. Below, I propose mechanisms to adapt the patent system to accommodate the realities of irreplicability while staying true to the goal of incentivizing innovation.

\section{Adapting Patent Law to an Irreplicable World}

These shifts in theory press towards policy change that - instead of assumes that patents work-allows the patent system and third parties to efficiently and inexpensively deal with patents that are not functional. Below, I discuss several potential policy changes to accommodate widespread irreplicability in the patent system. Note that because I have focused here on biomedical patents, I discuss these changes in the context of that industry. However, other industries also struggle with irreplicability, ${ }^{289}$ and the policy suggestions are applicable across fields, therefore, they may be beneficial beyond the life sciences.

\section{Clarify the Experimental Use Exception}

Since there is a high chance that an experiment in a patent will be irreplicable, we should make it easier for third parties to repeat the experiment in order to test whether or not it works. At present, such an attempt might be patent infringement. ${ }^{290}$ The possibility of an infringement lawsuit may deter scientists from trying to verify experiments in patents. There should be a clear experimental use exception-either common law or statutory-for attempted replication. This change would fit comfortably with Justice Story's original vision of the common law experimental use exception, which he believed was necessary "to ascertain the verity and exactness of the specification." 291

To increase the disclosure value of patents, that exception might be conditioned on the replicator publicly disclosing the results of their verification attempt. Ideally, this would be linked to the patent-perhaps the PTO could create comment or discussion sections appended electronically to each patent. While public comment sections undoubtedly have their problems, they work to flag replicability problems in the scientific literature. PubPeer, a commonly used commenting system, routinely causes retraction notices to be issued. ${ }^{292}$ If attempts at replication were linked to

Wasserman, Irrational Ignorance at the Patent Office, 72 VAND. L. REV. (forthcoming 2019).

287. See Lemley, supra note 38 , at 1510.

288. Id.

289. See Ouellette, supra note 16, at 605-06.

290. See supra Section III.A.4.

291. Sawin v. Guild, 21 F. Cas. 554, 555 (Story, Circuit Justice, C.C.D. Mass. 1813) (No. 12,391).

292. Stephen Buranyi, Anonymous Internet Vigilantes Are Taking Peer Review into Their 
patents, it might become clear that certain patents were not replicable. Even if those patents were not formally invalidated, the information could give those who wanted to work in the space covered by the patent's claims some confidence that the patent would not hold up in court.

\section{Ease Process of Invalidating Irreplicable Patents}

Because granted patents are given a presumption of validity, arguing that a patent is not enabled is a long, expensive, and uncertain process. If most patents contain irreplicable experiments - meaning that they are likely not to be enabled - then the presumption makes little sense. The evidence of irreplicability presented in this Article is a strong argument to remove the presumption of validity, at least when it comes to enablement. ${ }^{293}$

Similarly, it is worth considering faster and cheaper options to invalidate patents that are not enabled or useful. ${ }^{294}$ Inter partes review (IPR) proceedings have significantly brought down the cost of challenging a patent on novelty and nonobviousness grounds. ${ }^{295}$ The proceedings could be expanded to utility, enablement, and written description to ease the process of removing irreplicable patents. Further, if patents were easier to invalidate on these grounds, it might incentivize patent applicants to conduct better quality experiments before spending money on a patent application. Expanding IPR proceedings would not be straightforward. The advantages of IPRs are their low cost and speed, which rely on the proceeding's limited discovery. ${ }^{296}$ The legislative history of the America Invents Act, which created IPRs, demonstrates concern that including enablement in such proceedings would be difficult because of the necessary discovery ${ }^{297}$ Thus, an IPRlike proceeding on utility, enablement, or written description grounds would need to

Own Hands, MotherboARD (Oct. 3, 2016), https://motherboard.vice.com/en_us/article /pgkxey/anonymous-internet-vigilantes-are-taking-peer-review-into-their-own-hands -pubpeer [https://perma.cc/8JZ6-H8TA].

293. In other contexts, others have suggested rethinking the presumption of validity. See, e.g., John H. Barton, Reforming the Patent System, 287 ScI. 1933, 1934 (2000); F. Scott Kieff, The Case for Preferring Patent-Validity Litigation over Second-Window Review and GoldPlated Patents: When One Size Doesn't Fit All, How Could Two Do the Trick?, 157 U. PA. L. REV. 1937, 1940 (2009); Lichtman \& Lemley, supra note 34, at 47; Seymore, supra note 37, at 159 .

294. This is not all patents with irreplicable experiments, since a patent can contain an irreplicable experiment and still be valid. See supra Section I.B.1. However, it will include some of the worst offenders.

295. Ariel D. Multak, The Big Patent Short: Hedge Fund Challenges to Pharmaceutical Patents and the Need for Financial Regulation, 23 FordHAM J. CORP. \& FIN. L. 301, 307-09 (2017).

296. E.g., Stacy Lewis \& Tom Irving, Very Few Appreciated Just How Bad AIA Inter Partes Review (IPRS) Would Be for Patent Owners, Although IPR Denials Have Been, for Patent Owners, a Glimmer of Hope, 11 BufF. InTELl. Prop. L.J. 28, 32 (2015). For another discussion of using PTO proceedings in creative ways, see Dmitry Karshtedt, Contracting for a Return to the USPTO: Inter Partes Reexamination as the Exclusive Outlet for Licensee Challenges to Patent Validity, 51 IDEA 309, 309-10 (2011).

297. 157 Cong. ReC. S1375 (2011). 
be constrained in order to reduce discovery costs. Despite these challenges, it is important to think about ways to reduce the cost of challenging patents that cover inoperative technology.

\section{Disclose Ex Post Data}

Irreplicable experiments do not necessarily mean bad science; they just mean that the process of proving that something works is long and difficult. Since patents are inevitably filed before we have clear evidence that an invention works, it does not make sense to halt an inventor's disclosure duties at the time of patent filing. Incorporating ex post data is foreign to the US patent system but has been suggested in limited circumstances ${ }^{298}$ and is sometimes done in other countries. ${ }^{299}$ Such a system might require the patentee to update the patent with any data that bear directly on information provided in the patents. This could be done at the same time that maintenance fee payments are made, with the patentee swearing that all proper updates are made. This could create significant additional work for patentees. However, if we are serious about ensuring that patents disclose a working invention, there are only two possibilities: delay patenting until the invention is sure to work, or include ex post data in the patent. The latter is likely more palatable to patentees.

\section{Strategic Ex Ante Improvements}

As explained above, I favor strategies that will address irreplicability ex post, after patent grant, rather than at the PTO. Although a system where PTO examiners seek to enforce a replicability requirement would be unwieldy, there are certain ways in which the PTO is well positioned to improve replicability. In particular, we should take advantage of structural differences between the PTO and the scientific community. The scientific community's best experts have been struggling with this problem for over a decade - with limited success - but the PTO has two advantages that the scientific community does not: (1) it is centralized, and (2) examiners are paid. By contrast, scientific journals operate through a decentralized, norms-based system that relies heavily on volunteer peer reviewers - and consequently journals have found it difficult to enforce guidelines intended to enforce replicability. ${ }^{300}$

298. See Jeanne C. Fromer, Dynamic Patent Disclosure, 69 VAND. L. ReV. 1715, 1722 (2016); W. Nicholson Price II \& Arti K. Rai, Manufacturing Barriers to Biologics Competition and Innovation, 101 IowA L. REV. 1023, 1060 (2016).

299. For example, Australia allows inventors to add working examples to the specification as long as these examples do not encompass matter that was "not in substance disclosed" in the specification as filed. Shann Kerner, Andrej Barbic \& Kyle Robertson, Examples Requirements for Patentability of Inventions in U.S. and Foreign Jurisdictions, BLOOMBERG L. REP., Sept. 2009, 8, 11.

300. To improve study design and prevent publication of studies with inadequate methodological descriptions, over 300 groups have published guidelines or checklists on best practices in methodological design and reporting. Munafò et al., supra note 77, at 4 . These guidelines are aggregated by EQUATOR NETWORK, http://www.equator-network.org/ [https://perma.cc/SJD6-5WM6]. Several journals and grant-giving agencies now require submission of a checklist with each article or encourage their peer reviewers to use the 
The PTO could capitalize on these differences to require more disclosure for experiments. For example, journals believe that increased disclosure would improve replicability, and thousands of journals have tried to implement disclosure checklists to ensure that articles included key methodological details - but they have not yet been successful. ${ }^{301}$ Perhaps there is a role for patents. The PTO could adopt a checklist, such as the one used for this study, and require applicants to disclose the information on the checklist. The PTO would not have to generate its own list but could instead borrow a list already created by the scientific community. ${ }^{302}$ This change would not require additional work for patent applicants because, having done the experiment, they must know the information already - for instance, what sample size was used or whether the experiment was blinded. The change simply requires writing the details down. At present, they may not disclose because they do not want to (perhaps they are trying to overemphasize the importance of the results, or hide the key details needed to conduct the experiment), because they do not keep good records, or because the attorney does not bother to ask or include the details. None of these are good reasons to avoid disclosure.

Better disclosure of methodological details would not directly lead to improved replicability. An experiment that was poorly done does not become replicable just because readers know it was poorly done. However, it would vastly improve the ability of readers to assess the likelihood of replicability and understand the quality of the experiment. Readers could then discern which experiments appeared promising and worth trying and which should not be bothered with. This would be a significant improvement over the present state, where patent readers must simply guess. Further, it might incentivize the use of better methodology, since that methodology would be public.

Disclosure checklists are just one area where the PTO might be better positioned than the scientific community to improve replicability. The patent system and the scientific community have different strengths and should work together to address the replicability crisis that affects them both.

checklists. Unfortunately, most evidence shows that these measures are not working. For example, the Animal Research Reporting of In Vivo Experiments (ARRIVE) guidelines have been endorsed by over 300 journals, all major UK funding agencies, and the U.S. National Research Council Institute for Laboratory Animal Research. However, a study of the guidelines two years after their implementation found that there was widespread failure to comply with the guidelines among authors published in the very journals that had endorsed the guidelines. Baker et al., supra note 137, at 1. Similarly, in 2003, the National Academies of Science, Engineering, and Medicine drafted guidelines about what information should be included in publications to support replicability. A study done in 2012 found that, while the number of journals implementing these guidelines was increasing, only a small minority had policies implementing all guidelines. See Victoria Stodden, Peixuan Guo \& Zhaokun Ma, Towards Reproducible Computational Research: An Empirical Analysis of Data and Code Policy Adoption by Journals, PLoS ONE, June 2013.

301. See, e.g, Baker et al., supra note 137, at 3; Stodden et al., supra note 299, at 1-2.

302. This would mitigate problems caused by the PTO's lack of institutional expertise, although the PTO would still need the expertise to select a proper checklist. 


\section{CONCLUSION}

The replicability crisis afflicting experiments in scientific literature raises questions about the replicability of experiments in patents. These questions are of utmost importance to the patent system, since the assumptions of operability and replicability undergird many doctrines and goals of patent law. This Article provides the first empirical evidence that there is a replicability crisis in patents-that experimental testing described in patents is likely often irreplicable and unworkable. Significant harms arise from irreplicable patents, and the prevalence of such patents create concerns for legal doctrine, theory, and scholarship. After demonstrating the existence of a replicability crisis in patents, this Article pushes for reformulating current tests for whether an invention works, reformulating assumptions about the reliability of evidence in patents, and retheorizing conceptions of what it means for an invention to work. 